University of South Florida

DIGITAL COMMONS

@ UNIVERSITY OF SOUTH FLORIDA
Digital Commons @ University of

South Florida

\title{
8-1-2015
}

\section{Evaluation of HART MetroRapid BRT}

CUTR

Follow this and additional works at: https://digitalcommons.usf.edu/cutr_nctr

\section{Recommended Citation}

"Evaluation of HART MetroRapid BRT," National Center for Transit Research (NCTR) Report No. CUTRNCTR-RR-2015-09, Center for Urban Transportation Research, University of South Florida, 2015.

DOI: https://doi.org/10.5038/CUTR-NCTR-RR-2015-09

Available at: https://scholarcommons.usf.edu/cutr_nctr/75

This Technical Report is brought to you for free and open access by the National Center for Transit Research (NCTR) Archive (2000-2020) at Digital Commons @ University of South Florida. It has been accepted for inclusion in Research Reports by an authorized administrator of Digital Commons @ University of South Florida. For more information, please contact digitalcommons@usf.edu. 


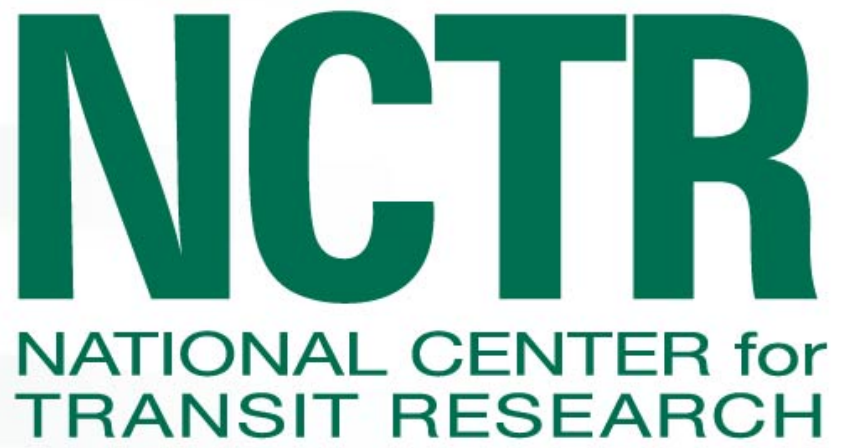

Evaluation of HART MetroRapid BRT

August 2015

FINAL REPORT 


\section{Metric Conversion}

\begin{tabular}{|c|c|c|c|c|}
\hline SYMBOL & WHEN YOU KNOW & MULTIPLY BY & TO FIND & SYMBOL \\
\hline \multicolumn{5}{|c|}{ LENGTH } \\
\hline in & inches & 25.4 & millimeters & $\mathrm{mm}$ \\
\hline $\mathrm{ft}$ & feet & 0.305 & meters & $\mathrm{m}$ \\
\hline yd & yards & 0.914 & meters & $\mathrm{m}$ \\
\hline mi & miles & 1.61 & kilometers & $\mathrm{km}$ \\
\hline \multicolumn{5}{|c|}{ VOLUME } \\
\hline fl oz & fluid ounces & 29.57 & milliliters & $\mathrm{mL}$ \\
\hline gal & gallons & 3.785 & liters & $\mathrm{L}$ \\
\hline $\mathrm{ft}^{3}$ & cubic feet & 0.028 & cubic meters & $\mathrm{m}^{3}$ \\
\hline$y d^{3}$ & cubic yards & 0.765 & cubic meters & $\mathrm{m}^{3}$ \\
\hline \multicolumn{5}{|c|}{ Note: volumes greater than $1000 \mathrm{~L}$ shall be shown in $\mathrm{m}^{3}$} \\
\hline \multicolumn{5}{|c|}{ MASS } \\
\hline oz & ounces & 28.35 & grams & g \\
\hline lb & pounds & 0.454 & kilograms & $\mathrm{kg}$ \\
\hline $\mathbf{T}$ & short tons $(2000 \mathrm{lb})$ & 0.907 & $\begin{array}{c}\text { megagrams } \\
\text { (or metric } \\
\text { ton) }\end{array}$ & $\begin{array}{l}\text { Mg (or } \\
\text { "t") }\end{array}$ \\
\hline \multicolumn{5}{|c|}{ TEMPERATURE (exact degrees) } \\
\hline${ }^{\circ} \mathbf{F}$ & Fahrenheit & $\begin{array}{c}5(F-32) / 9 \text { or } \\
(F-32) / 1.8\end{array}$ & Celsius & ${ }^{\circ} \mathrm{C}$ \\
\hline
\end{tabular}


Technical Report Documentation

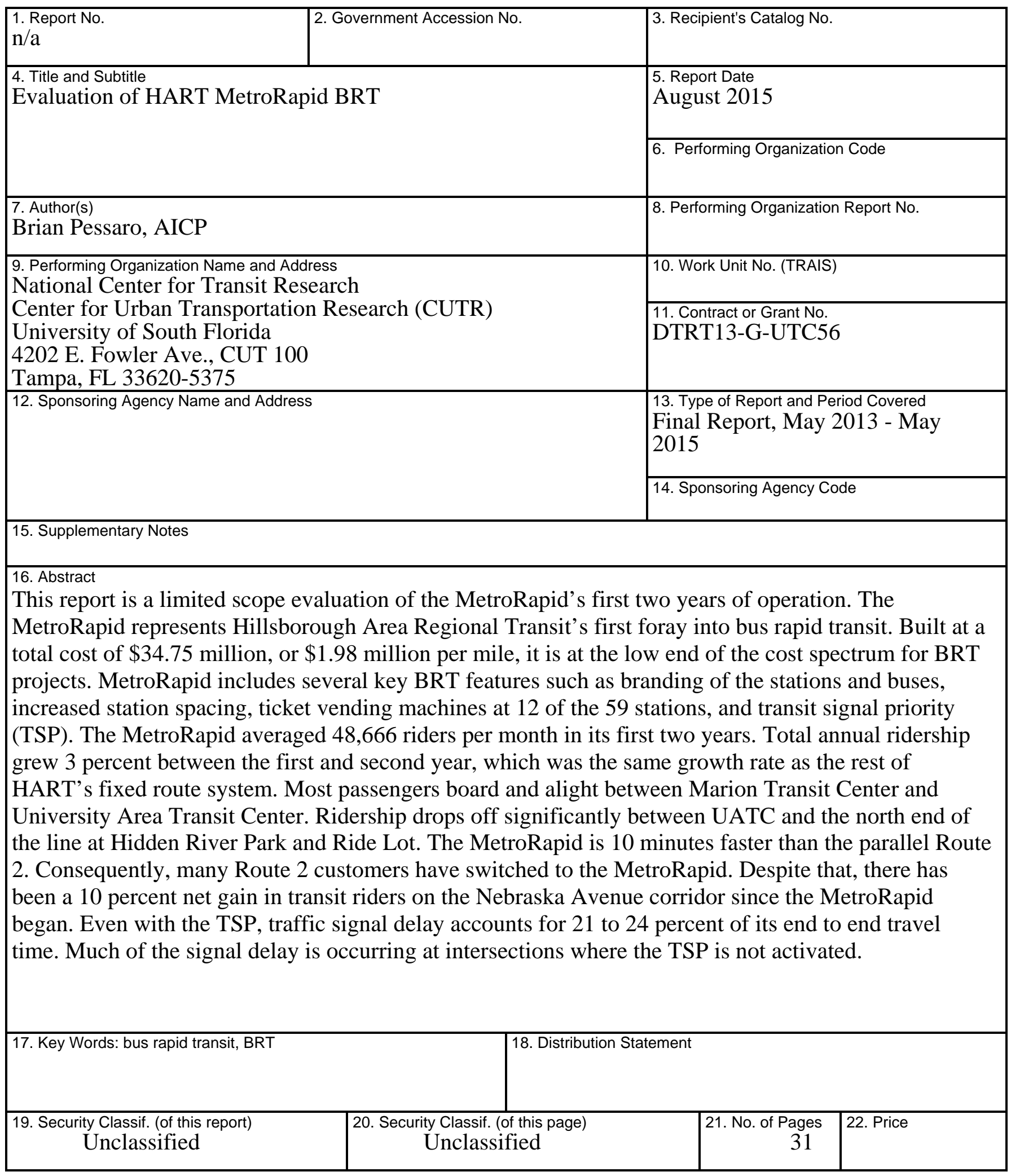




\section{Acknowledgements}

The author would like to thank Justin Begley at HART for his assistance with providing data for the report. The author would also like to thank the following individuals for their help with field data collection: Lisa Beyer, Jennifer Flynn, Max Mantius, Joseph Michalksy, Angelo Pessaro, Uday Siramdasu, Cheryl Thole, and Abhijit Vasili. 


\section{Executive Summary}

As of May 2015, the Metro-Rapid has been in service for two years. Over that time, it has averaged 48,666 riders per month. Total annual ridership grew 3 percent between its first and second year of operation, which was the same growth rate as the rest of HART's fixed route system. Many riders from the parallel Route 2 (Nebraska Avenue) have switched to the MetroRapid to take advantage of the faster service. In fact, ridership on the Route 2 dropped 30 percent in June 2013, the MetroRapid's first full month of operation. Despite that, there has been a 10 percent net gain in riders in the Nebraska Avenue corridor since the MetroRapid began. Among the 46 routes in HART's system, the MetroRapid ranks $23^{\text {rd }}$ in passengers carried per revenue hour and $18^{\text {th }}$ in passengers carried per revenue mile. It carries 19.41 passengers per revenue hour and 1.58 passengers per revenue mile.

The MetroRapid is faster and more reliable than the Route 2. Because of the transit signal priority (TSP) and wider spaced stations, it runs 10 minutes faster and is more consistent than the Route 2 in the amount of time it takes to travel the corridor. Based on the field observations that were made, dwell time and turn out delay is not an issue on the MetroRapid. Neither is crosswalk delay at the new crosswalks on Fletcher Avenue. Signal delay, on the other hand, accounts for between 21 and 24 percent of the end to end travel time. The intersections with the greatest signal delay are Hillsborough Avenue (103 seconds on average) and Busch Boulevard (110 seconds on average). There is also a string of signal delays in downtown Tampa along Morgan Street near the Marion Transit Center. Individually, they are small in magnitude, but collectively they add up to 57 seconds on average. None of these intersections have the TSP activated. HART has inquired about making these downtown signals TSP capable. However, the City of Tampa's downtown signal system is tightly coordinated and cannot accommodate TSP at this time.

Using automated passenger count (APC) data, the analysis shows that the vast majority of boarding and alighting activity occurs at the Marion and University Area Transit Centers (UATC). However, there is also a steady stream of activity at Hillsborough Avenue, Waters Avenue, MLK Jr. Boulevard, and Columbus Drive. The data shows also that boarding and alighting drops off significantly once the bus is east of UATC on Fletcher Avenue. This indicates that the MetroRapid is not being used as much as it could be in the area around the University of South Florida.

The on-board passenger survey revealed important information about MetroRapid riders. Like other riders on HART's system, most do not own a car (61\% MetroRapid; 63\% HART). In regards to transfers, 45 percent said they transferred before getting on the MetroRapid, and 43 percent said they would transfer after getting off. The top three routes that riders transferred from were Route 34 (Hillsborough Avenue), Route 6 (56th Street), and Route 2 (Nebraska Avenue). The top two routes that riders transferred to were Route 34 (Hillsborough Avenue) and Route 6 (56th Street). Although the MetroRapid has ticket vending machines at 12 stations, only 25 percent of the riders reported using them. Overall, riders are happy with the service. When rating nine factors of service on a scale of 1 to 5 with 5 being the best, all but one of the factors 
had a score of 4 or greater. The service factor hours of service rated a 3.9. This helps to explain why 64 percent of riders reported also riding the Route 2. Most likely, they are riding the Route 2 at night or on the weekend when the MetroRapid is not in service. Finally, 45 percent of MetroRapid riders reported using the OneBus Away phone app. 


\section{Table of Contents}

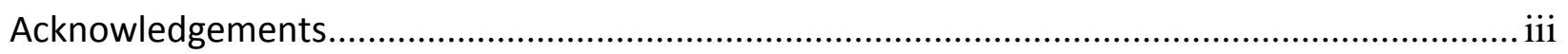

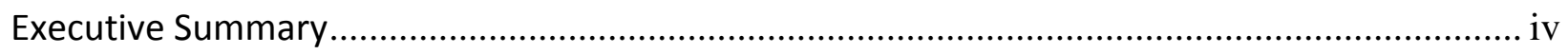

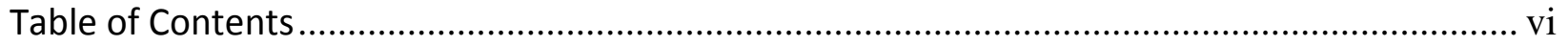

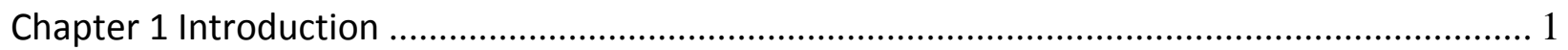

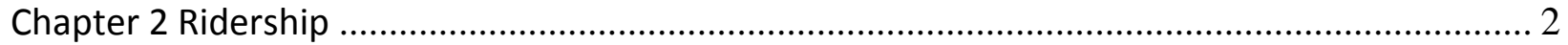

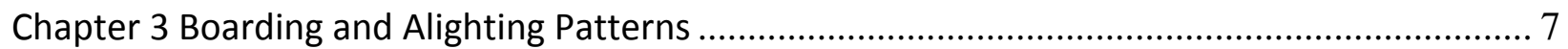

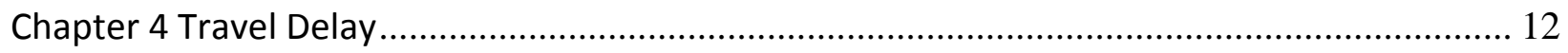

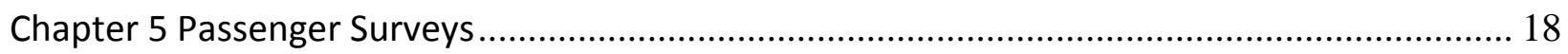

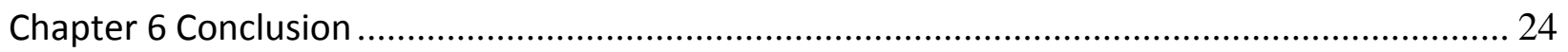

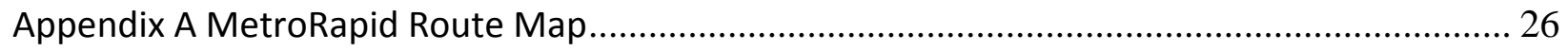

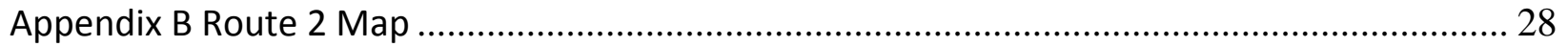

Appendix C Station Type/Ticket Vending Machine Location Map .......................................... 30 


\section{List of Figures}

Figure 1-1 MetroRapid Bus and Station................................................................................ 1

Figure 2-1 Monthly Riders on MetroRapid June 2013 to May 2015 ............................................... 2

Figure 2-2 Monthly Riders MetroRapid vs Route 2 .............................................................. 3

Figure 2-3 Passengers per Revenue Hour per Route FY 2015 (10/1/2014 - 5/31/2015) .............. 5

Figure 2-4 Passengers per Revenue Mile per Route FY 2015 (10/1/2014 - 5/31/2015) ................ 6

Figure 3-1 Northbound Boardings and Alightings March 2014 ................................................... 8

Figure 3-2 Northbound Boardings and Alightings March 2015 ................................................... 9

Figure 3-3 Southbound Boardings and Alightings March 2014 .................................................. 10

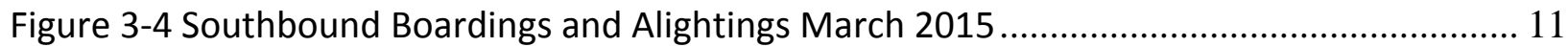

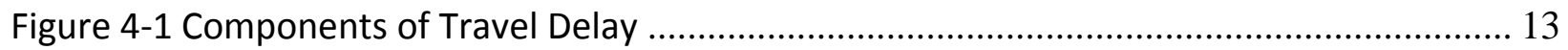

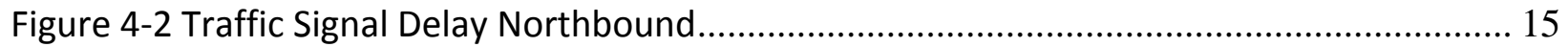

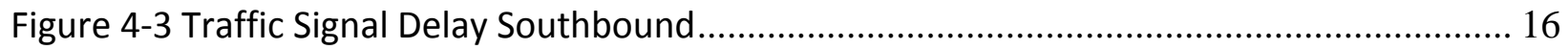

\section{List of Tables}

Table 2-1 Net Increase in Riders ................................................................................................... 4

Table 2-2 Cumulative Ridership Comparison HART Fixed Route Bus vs MetroRapid ..................... 4

Table 4-1 Departure Times Captured for Measuring Travel Delay............................................... 12

Table 4-2 Travel Time Comparison for MetroRapid and Route 2 (March 2015) .......................... 17

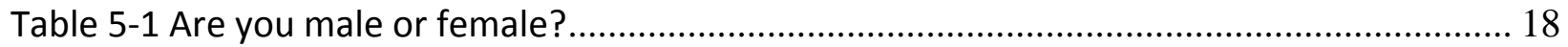

Table 5-2 How many automobiles do you have in your household? ...................................... 18

Table 5-3 How would you make this trip is not by bus? .............................................................. 19

Table 5-4 Before getting on the MetroRapid, did you transfer from another route? .................. 19

Table 5-5 After you leave the MetroRapid, will you transfer to another route? .......................... 19

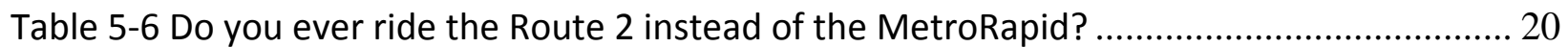

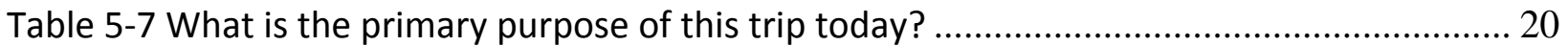

Table 5-8 How many days a week do you ride the MetroRapid?.................................................. 20

Table 5-9 Did you use the ticket vending machine to purchase your ticket? ................................. 21

Table 5-10 Cross Tabulation (Frequency of Riding vs. Use of TVM) .............................................. 21

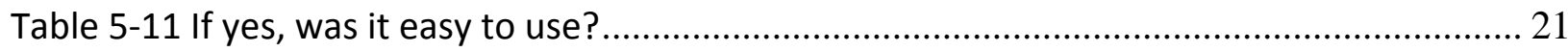

Table 5-12 Level of Importance and Level of Satisfaction with Various Travel Factors................ 22

Table 5-13 Levels of Satisfaction by Gender ............................................................................. 22

Table 5-14 Do you use the OneBusAway phone app?................................................................ 23 


\section{Chapter 1 Introduction}

The North-South Metro-Rapid began service at the end of May 2013 and represents Hillsborough Area Regional Transit's (HART) first foray into bus rapid transit. The MetroRapid operates on a 17.5 mile corridor on Fletcher Avenue and Nebraska Avenue (see Appendix A MetroRapid Route Map). The northern terminus is the Hidden River Park and Ride Lot near I-75 and the southern terminus is the Marion Transit Center in downtown Tampa. Features of the Metro-Rapid include branding of both the stations and buses (Figure 1-1). There are 59 stations total, 12 of which are equipped with ticket vending machines (TVMs). A total of 37 intersections along the route are equipped with transit signal priority (TSP), of which 14 are in Hillsborough County and 23 are in the City of Tampa. All 14 of the county intersections and 8 of the 23 city intersections have the TSP activated. The MetroRapid runs every 15 minutes on Nebraska Avenue and every 30 minutes on Fletcher Avenue. It operates from 5 a.m. to 8 p.m. on weekdays only. Total project cost was $\$ 34.75$ million. That included $\$ 31$ million for design, land acquisition, and construction, $\$ 1.75$ million for the Hidden River Regional Park and Ride Lot, and $\$ 2$ million for the TSP. At the time of this report, the MetroRapid has been in operation for two years.

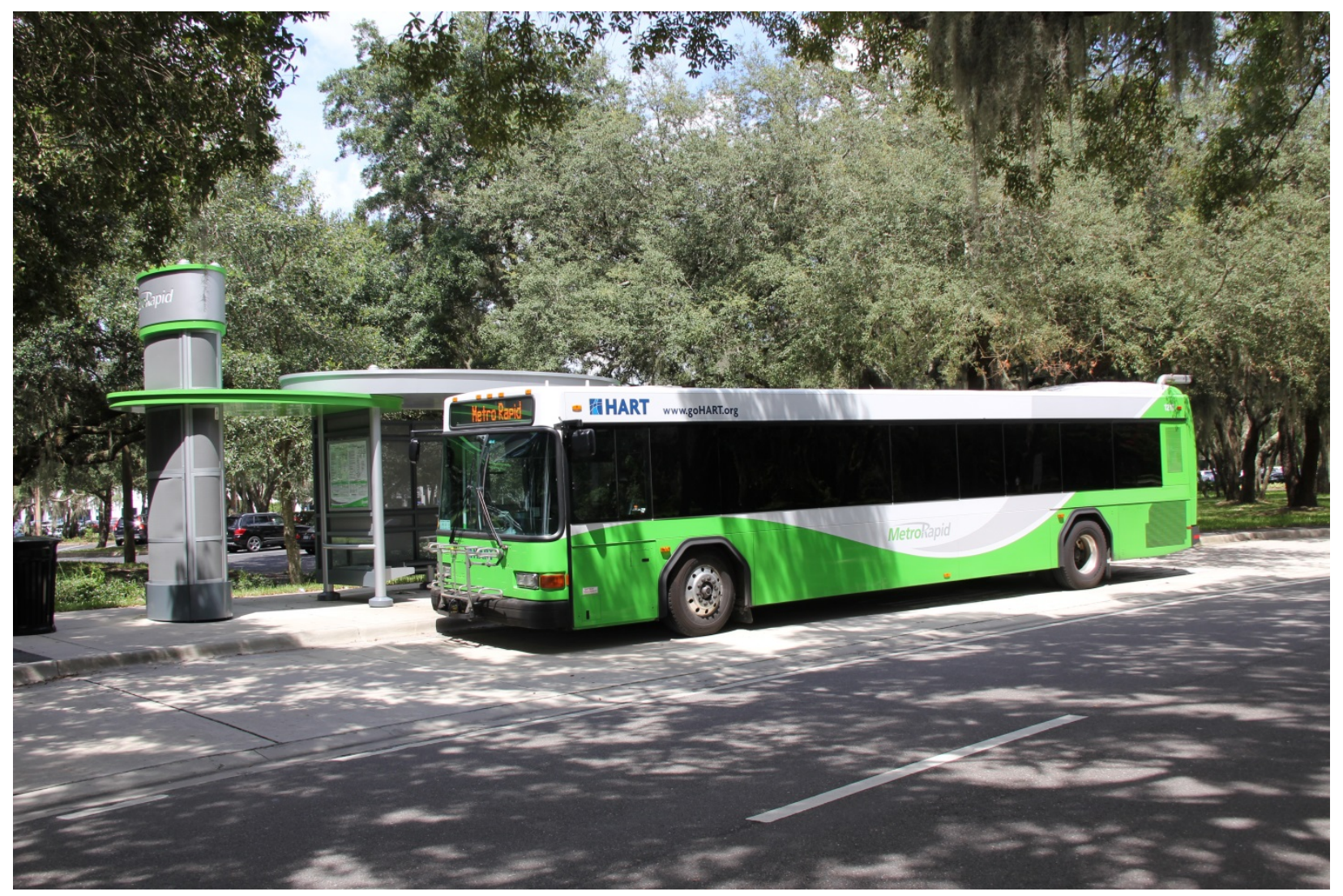

Source: CUTR

Figure 1-1 MetroRapid Bus and Station 


\section{Chapter 2 Ridership}

In June 2013, the first full month of operation, the MetroRapid carried 38,586 riders. In May 2015, it carried 45, 582 riders (Figure 2-1). The two-year average has been 48,666 riders per month.

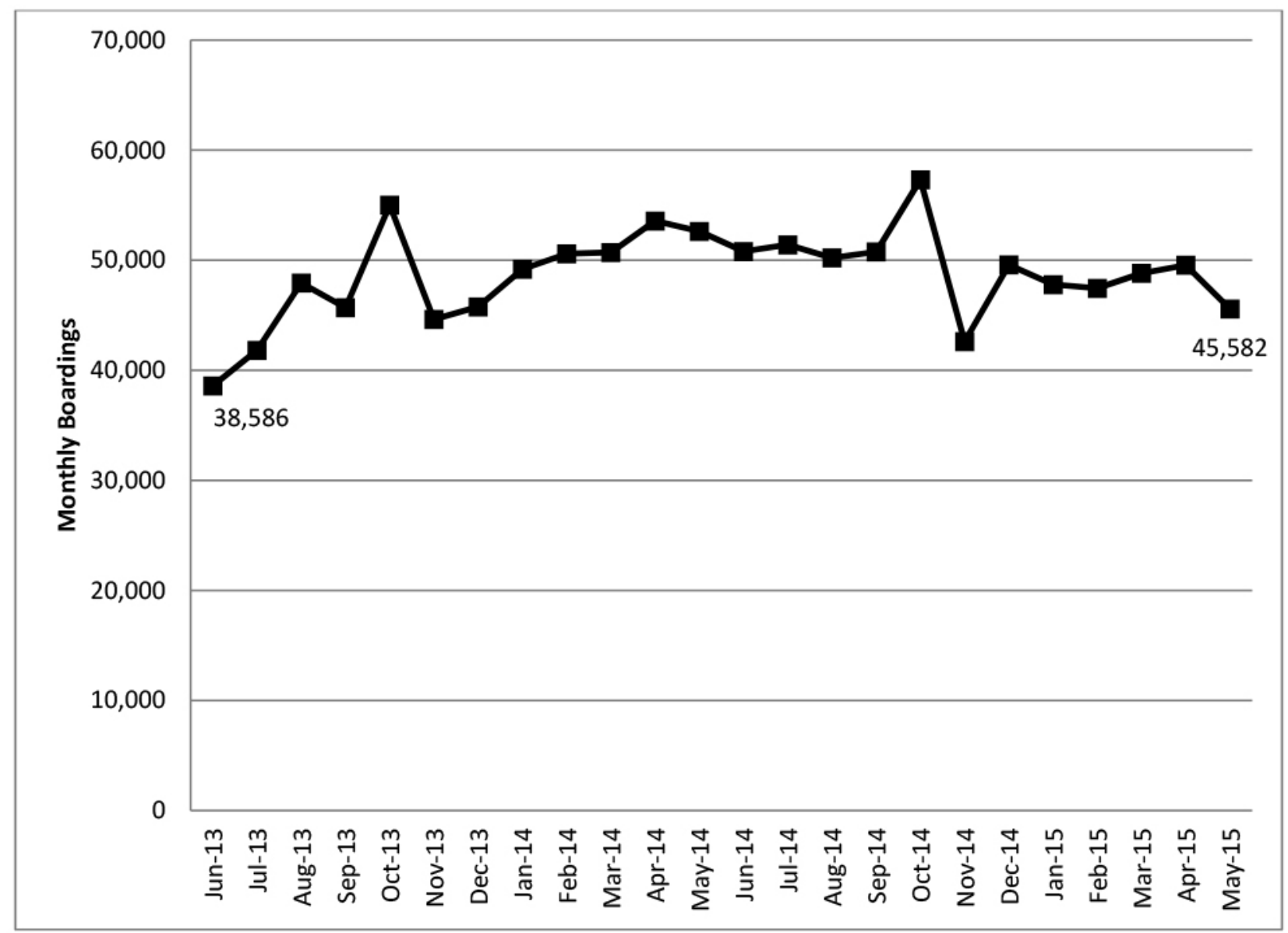

Figure 2-1 Monthly Riders on MetroRapid June 2013 to May 2015

Ridership on the MetroRapid was compared to ridership on the Route 2 (Nebraska Avenue). These two routes overlap on Nebraska and Fletcher Avenues between the Marion Transit Center in downtown Tampa and the University Area Transit Center (UATC). However, there are differences between the two. While the Route 2 turns around at UATC, the MetroRapid continues further east on Fletcher Avenue to the Hidden River Regional Park and Ride lot near I75. Maps for the MetroRapid and Route 2 can be found in Appendix A MetroRapid Route Map and Appendix B Route 2 Map, respectively. The MetroRapid has 15-minute service on Nebraska Avenue and 30-minute service on Fletcher Avenue. The Route 2 has 30-minute service on Nebraska Avenue. The MetroRapid only operates until 8 p.m. and only on weekdays while the Route 2 operates until 1 a.m. and also has Saturday and Sunday service. 
As shown in Figure 2-2, many riders from the Route 2 have shifted to the MetroRapid, presumably to take advantage of the faster service. In fact, ridership on the Route 2 dropped 30 percent in June 2013, the MetroRapid's first full month of service. That drop in ridership has persisted to the present day. As will be reported later in Chapter 5 (Passenger Surveys), 64 percent of MetroRapid riders said they also take the Route 2 (see Table 5-6). Based on anecdotal information heard during the survey collection, MetroRapid riders rely on the Route 2 as a fallback in the evening hours or on the weekend when the MetroRapid is not in service.

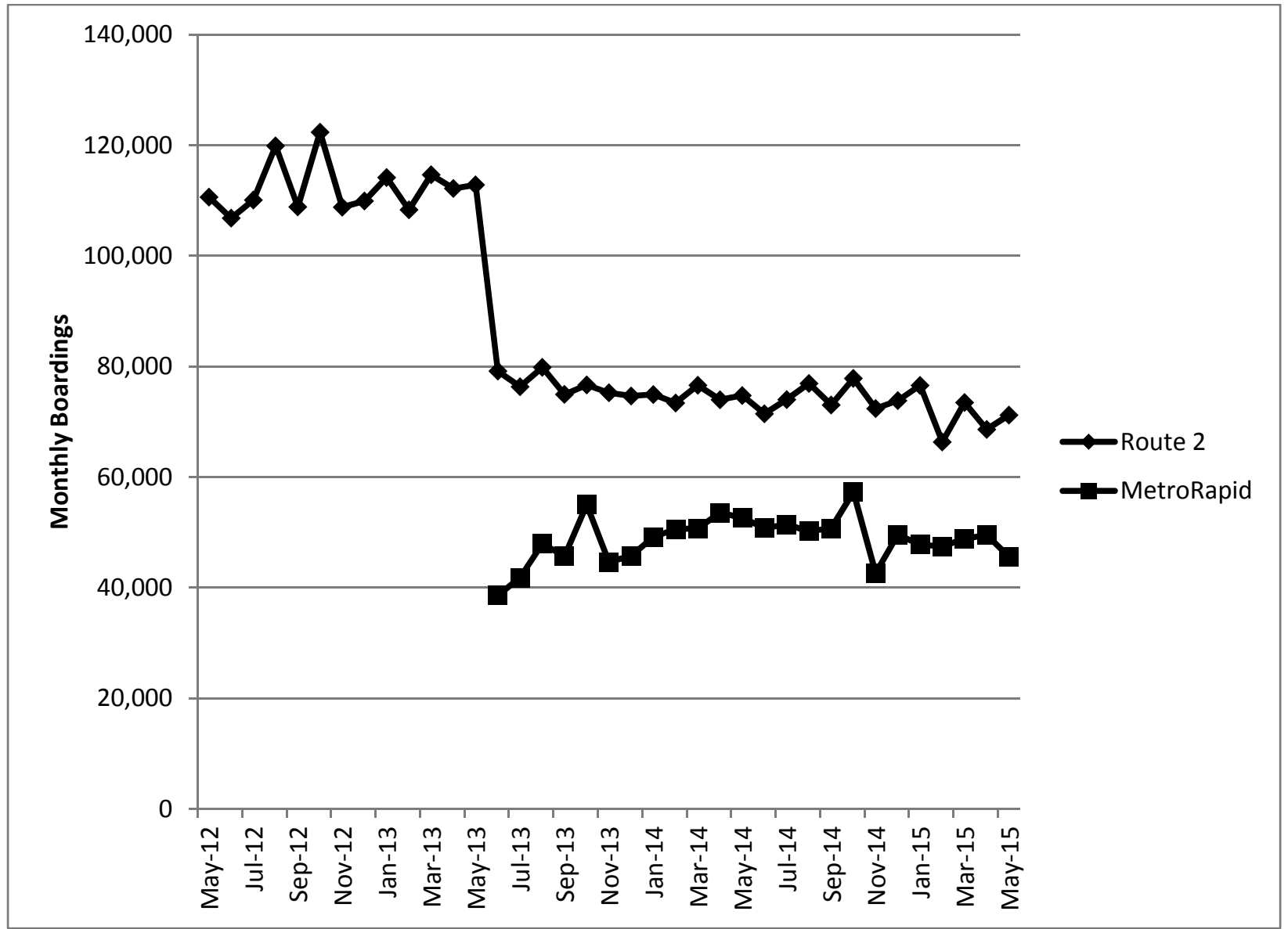

Figure 2-2 Monthly Riders MetroRapid vs Route 2

Notwithstanding that many Route 2 have switched to the MetroRapid, the question remains as to whether there has been a net gain in riders on the Nebraska Avenue corridor. To answer that question, ridership on the Route 2 for the year prior to MetroRapid was compared to combined ridership on Route 2 and MetroRapid for the following two years. As shown in Table 2-1, there was a 10 percent increase from 2013 to 2014 and then a 1 percent decrease from 2014 to 2015. Some of that 10 percent increase is due to the fact that the MetroRapid covers a larger area than the Route 2. While the Route 2 turns around at the University Area Transit Center near USF, the MetroRapid continues east on Fletcher Avenue to the Hidden River Park and Ride Lot. Strictly speaking, the numbers shown in Table 2-1 are not an apples-to-apples comparison. However, as will be explained in the next section of the report, most of the MetroRapid's boardings and alightings occur between the Marion Transit Center in downtown Tampa and the 
University Area Transit Center, which are the same route termini as the Route 2 . The number of boardings and alightings on the MetroRapid between UATC and the Hidden River Park and Ride Lot is negligible. What this means is that most of that 10 percent increase in ridership can be marked up as "new riders".

Table 2-1 Net Increase in Riders

\begin{tabular}{|c|c|c|c|}
\hline & $\begin{array}{c}1 \text { Year Before } \\
\text { MetroRapid }\end{array}$ & $\begin{array}{c}1 \text { Year After } \\
\text { MetroRapid }\end{array}$ & $\begin{array}{c}2 \text { Years After } \\
\text { MetroRapid }\end{array}$ \\
\hline Total Corridor Riders & $1,349,142$ & $1,486,723$ & $1,467,685$ \\
\hline \% Change & & $10 \%$ & $-1 \%$ \\
\hline
\end{tabular}

Ridership figures are total annual riders.

1 Year Before MetroRapid = June 2012 to May 2013 (Route 2 only)

1 Year After MetroRapid = June 2013 to May 2014 (Route 2 + MetroRapid)

2 Years After MetroRapid = June 2014 to May 2015 (Route 2 + MetroRapid)

Next, ridership growth on the MetroRapid was compared to ridership growth for the rest of HART's fixed route bus service as a whole. Table 2-2 shows that both increased 3 percent.

Table 2-2 Cumulative Ridership Comparison HART Fixed Route Bus vs MetroRapid

\begin{tabular}{|l|c|c|c|}
\hline & $\begin{array}{c}\text { June 2013 - } \\
\text { May 2014 }\end{array}$ & $\begin{array}{c}\text { June 2014 - } \\
\text { May 2015 }\end{array}$ & $\begin{array}{c}\text { Percent } \\
\text { Change }\end{array}$ \\
\hline All Fixed Route Bus & $14,742,731$ & $15,163,600$ & $3 \%$ \\
\hline MetroRapid & 576,113 & 591,875 & $3 \%$ \\
\hline
\end{tabular}

Ridership figures are total annual riders.

Related to ridership is the passengers carried per revenue hour. This is a measure of service effectiveness, which is the relationship between service output and service consumption. For example, if two routes ( $A$ and $B$ ) carry the same total passengers, but Route $A$ has twice the service hours, that means Route $B$ has a higher rate of service consumption. Figure 2-3 shows the passengers per revenue hour per route for the 46 routes in HART's system. The Route 2 ranked first, carrying 35.01 passengers per revenue hour. The MetroRapid ranked $23^{\text {rd }}$, carrying 19.41 passengers per revenue hour. This means that the Route 2 , even with the diversion of riders to the MetroRapid, has a higher rate of service consumption (i.e. it is more effective). 


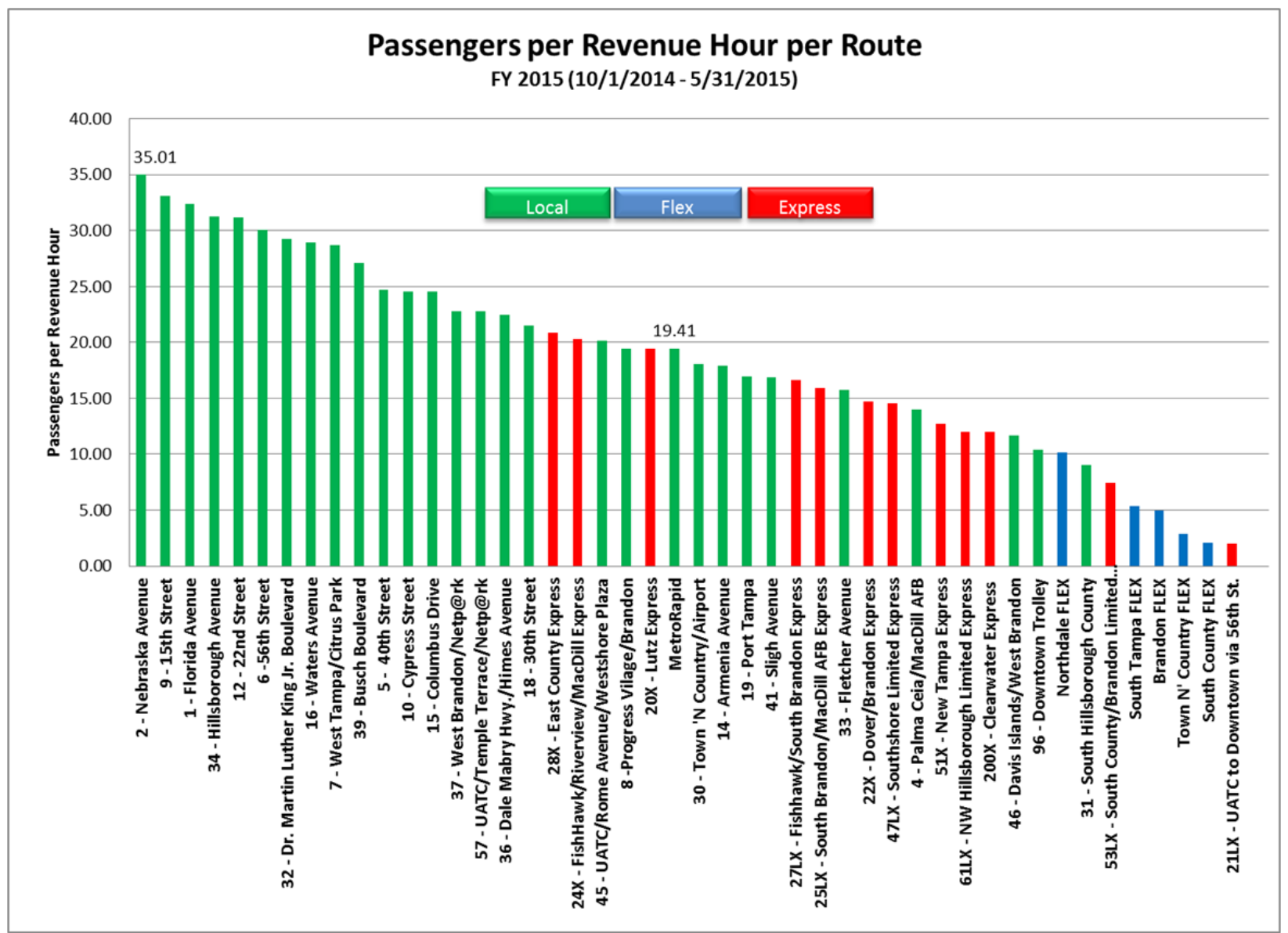

Figure 2-3 Passengers per Revenue Hour per Route FY 2015 (10/1/2014 - 5/31/2015)

It is worth pointing out that the Route 2 has approximately twice the number of bus stops as the MetroRapid. This gives the Route 2 an advantage over the MetroRapid for short distance trips.

Another measure of service effectiveness is passengers carried per revenue mile. Figure 2-4 shows the passengers carried per revenue mile for the 46 routes in HART's system, and once again the Route 2 is ranked first at 3.4 passengers per revenue mile. The MetroRapid is ranked $18^{\text {th }}$ at 1.58 passengers per revenue mile. 


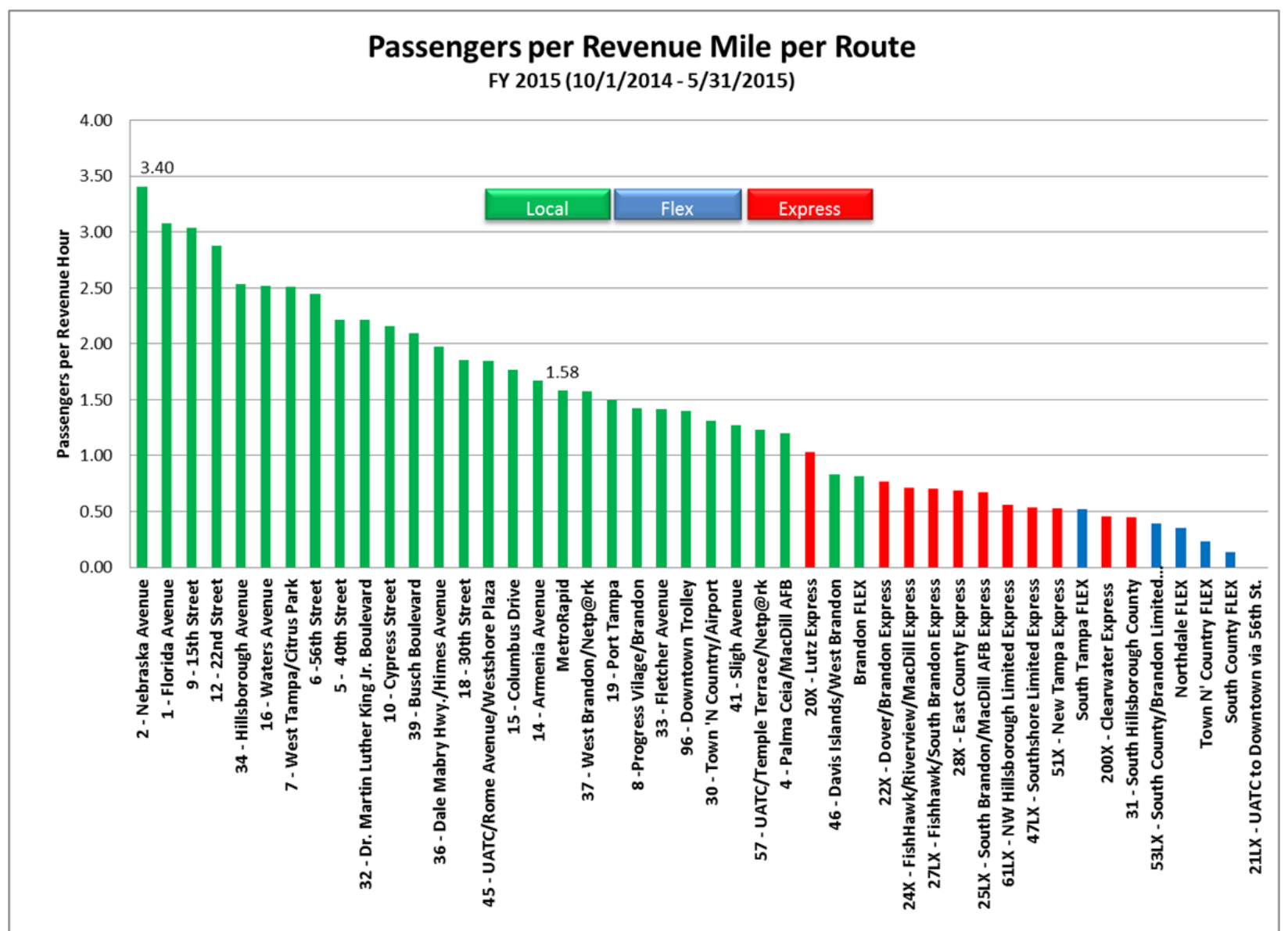

Figure 2-4 Passengers per Revenue Mile per Route FY 2015 (10/1/2014 - 5/31/2015) 


\section{Chapter 3 Boarding and Alighting Patterns}

Passenger boarding and alighting data (i.e. on/offs) was compared for March 2014 and March 2015. Since 100 percent of the MetroRapid fleet is equipped with automated passenger counters (APCs), it is possible to pinpoint where riders are getting on and off with a high degree of accuracy. The on/off data was examined by direction. There are four figures on the following pages:

- Northbound Boardings and Alightings March 2014

- Northbound Boardings and Alightings March 2015

- Southbound Boardings and Alightings March 2014

- Southbound Boardings and Alightings March 2015

When comparing the data from 2014 to 2015, there is not much difference in the distribution of on/offs in either direction. Most of the activity occurs at the Marion and University Area Transit Centers. There is also a steady stream of activity at Hillsborough Avenue, Waters Avenue, MLK Jr. Boulevard, and Columbus Drive.

One thing that stands out in all four figures is that boarding and alighting drops off significantly once the bus is east of UATC on Fletcher Avenue. Similarly, there is excess capacity at the Hidden River Regional Park and Ride lot. Students and commuters going to USF could potentially save money by parking for free at Hidden River instead of paying to park on campus. However, that potential remains untapped so far. Are they not using the Hidden River lot because they are unaware of it? HART staff has indicated that there has not been much advertising of this lot to USF. Is it because the MetroRapid only operates every 30 minutes on Fletcher Avenue or because USF commuters would still have to connect to the USF Bull Runner in order to get to their destination on campus? The answer at this point is unknown. 


\section{Northbound Boardings and Alightings}

March 2014

Weekday 5:00 a.m. $-6: 45$ p.m.

2,497 On/Offs Total

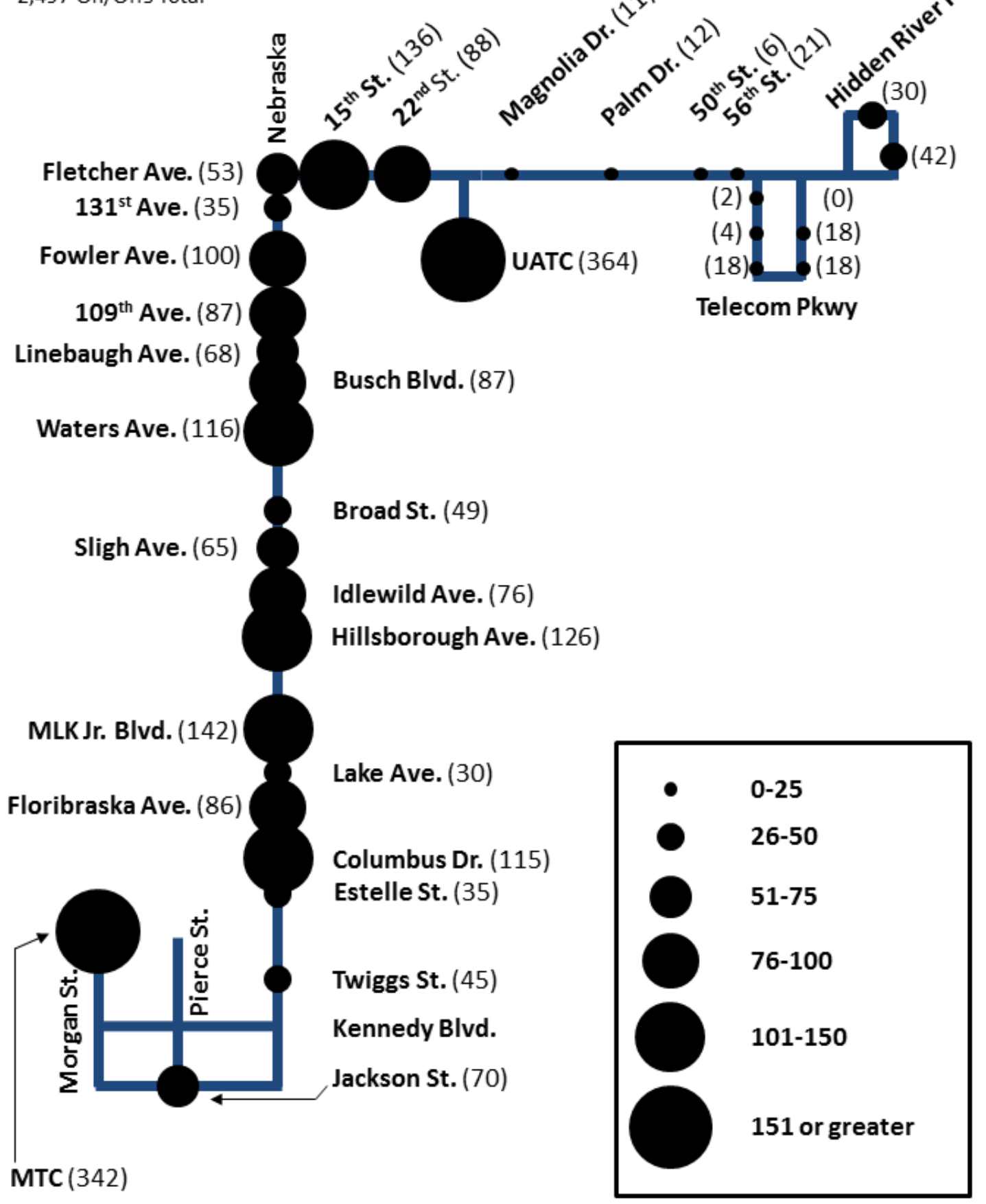

Note: Figures are average daily figures.

Figure 3-1 Northbound Boardings and Alightings March 2014 


\section{Northbound Boardings and Alightings}

March 2015

Weekday 5:00 a.m. $-6: 45$ p.m.

2,417 On/Offs Total

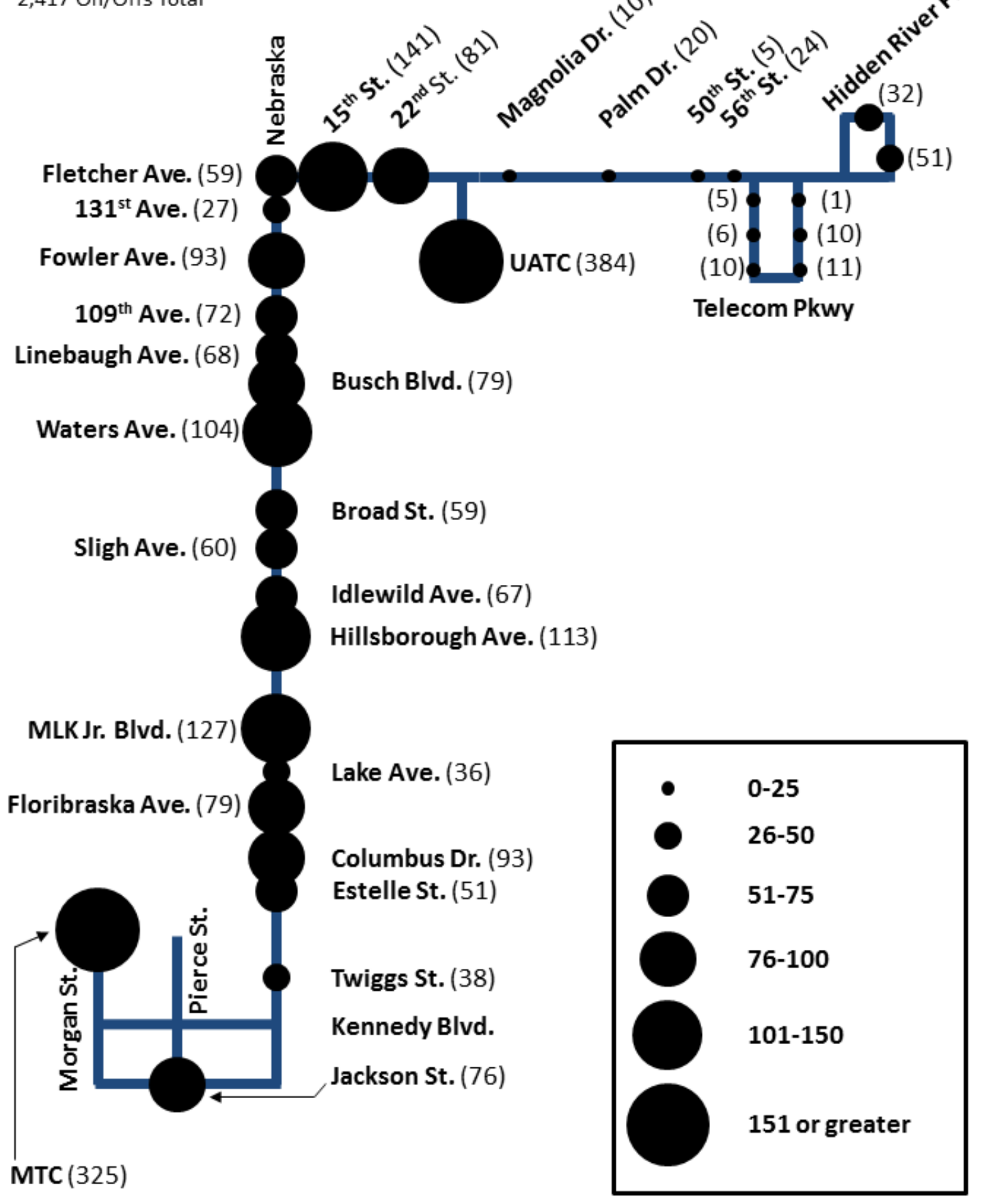

Note: Figures are average daily figures.

Figure 3-2 Northbound Boardings and Alightings March 2015 


\section{Southbound Boardings and Alightings}

March 2014

Weekday 5:15 a.m. - 7:20 p.m.

2,483 On/Offs Total

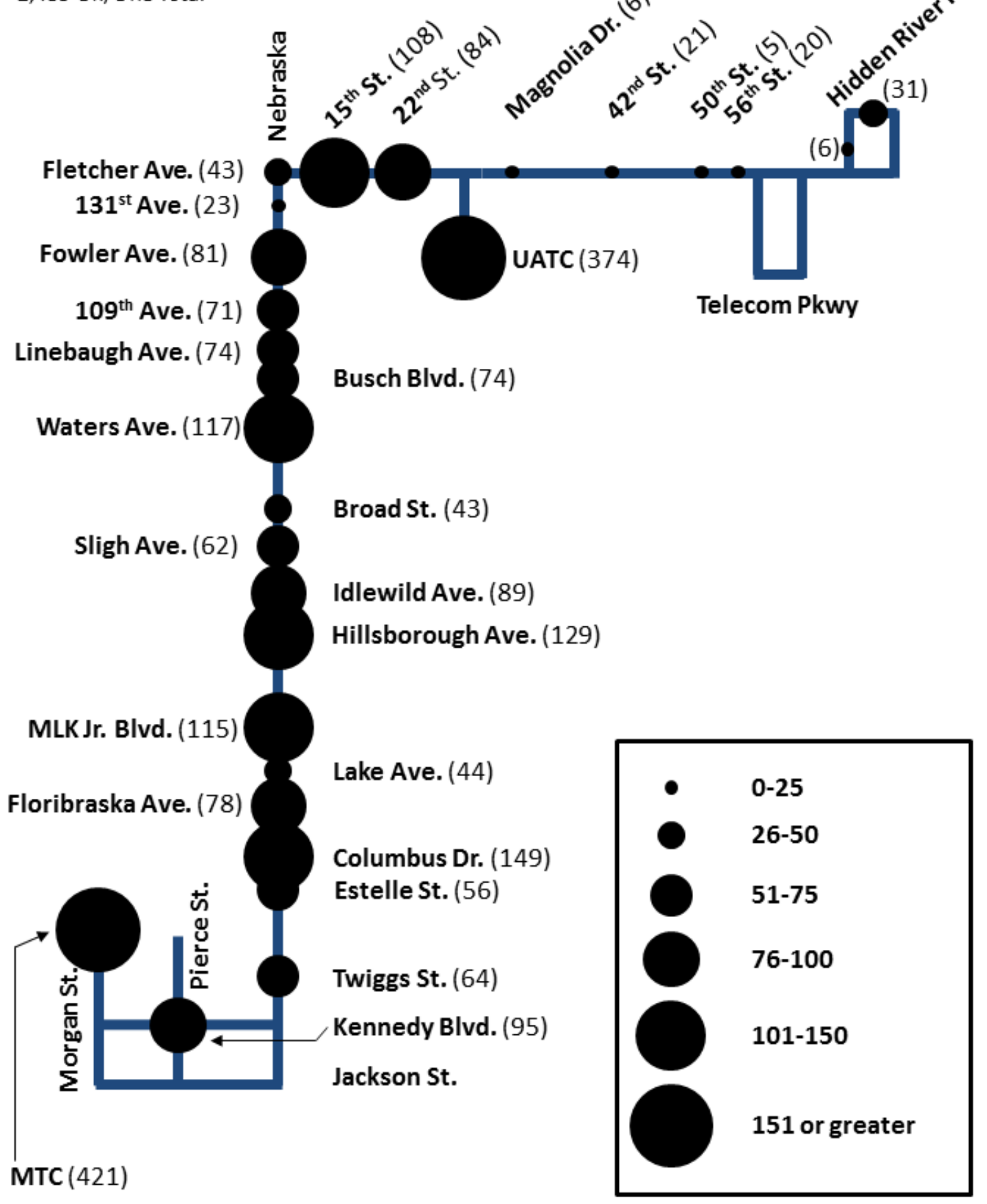

Note: Figures are average daily figures.

Figure 3-3 Southbound Boardings and Alightings March 2014 


\section{Southbound Boardings and Alightings}

March 2015

Weekday 5:15 a.m. - 7:20 p.m.

2,394 On/Offs Total

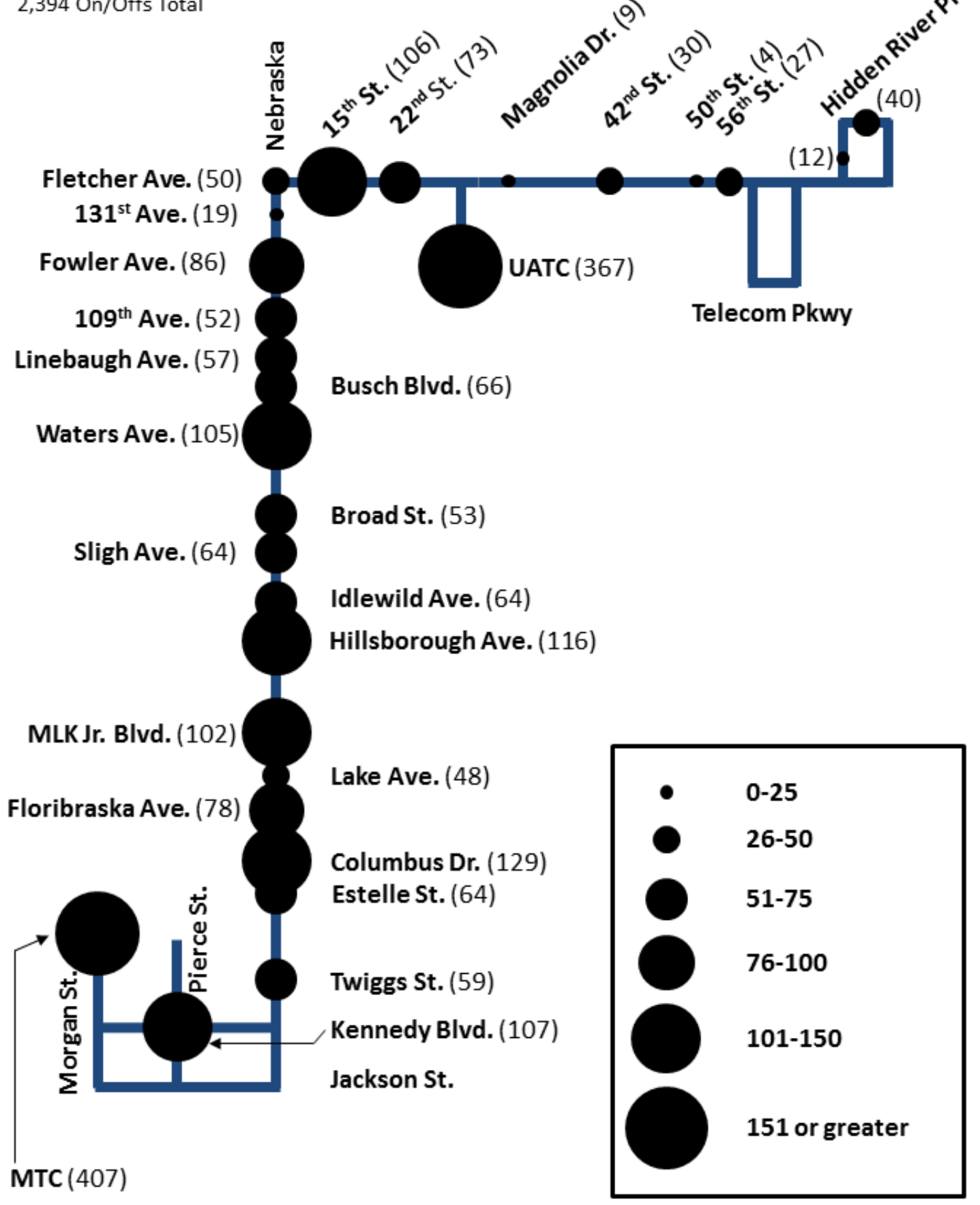

Note: Figures are average daily figures.

Figure 3-4 Southbound Boardings and Alightings March 2015 


\section{Chapter 4 Travel Delay}

In order to better understand the extent and nature of travel delay along the route, data collectors rode the MetroRapid and collected field data. Using a stopwatch and tracking sheet, the data collectors recorded the time, location, and nature of each delay event (e.g., dwell time, turn out delay, signal delay, crosswalk delay). Data was collected between April 13 and 20,2015 . A total of 15 trips were captured in the northbound direction and 16 trips in the southbound direction. The departure times of the trips that were captured are shown in Table 4-1. The intent was to focus on the morning and afternoon peak periods when delays would be more likely and more severe. By collecting the data over several days instead of just one, the chance of anomalous traffic conditions skewing the results was minimized.

Table 4-1 Departure Times Captured for Measuring Travel Delay

\begin{tabular}{|c|c|c|c|}
\hline \multicolumn{2}{|c|}{ Northbound } & \multicolumn{2}{c|}{ Southbound } \\
\hline Departure time/date from MTC & Departure time from Hidden River \\
\hline Time & Date & Time & Date \\
\hline 6:30 a.m. & $4 / 20 / 2015$ & $5: 15$ a.m. & $4 / 20 / 2015$ \\
\hline 7:00 a.m. & $4 / 20 / 2015$ & $5: 45$ a.m. & $4 / 20 / 2015$ \\
\hline 7:30 a.m. & $4 / 13 / 2015$ & $6: 15$ a.m. & $4 / 13 / 2015$ \\
\hline 8:00 a.m. & $4 / 20 / 2015$ & $6: 45$ a.m. & $4 / 20 / 2015$ \\
\hline 8:30 a.m. & $4 / 15 / 2015$ & $7: 15$ a.m. & $4 / 15 / 2015$ \\
\hline 9:00 a.m. & $4 / 20 / 2015$ & $7: 45$ a.m. & $4 / 20 / 2015$ \\
\hline 9:30 a.m. & $4 / 20 / 2015$ & $8: 15$ a.m. & $4 / 20 / 2015$ \\
\hline 10:00 a.m. & $4 / 13 / 2015$ & $8: 45$ a.m. & $4 / 13 / 2015$ \\
\hline 10:30 a.m. & $4 / 20 / 2015$ & $9: 15$ a.m. & $4 / 20 / 2015$ \\
\hline 11:00 a.m. & $4 / 15 / 2015$ & $9: 45$ a.m. & $4 / 15 / 2015$ \\
\hline 3:00 p.m. & $4 / 21 / 2015$ & $1: 45$ p.m. & $4 / 21 / 2015$ \\
\hline $4: 00$ p.m. & $4 / 17 / 2015$ & $2: 45$ p.m. & $4 / 17 / 2015$ \\
\hline $4: 30$ p.m. & $4 / 15 / 2015$ & $3: 15$ p.m. & $4 / 15 / 2015$ \\
\hline 5:30 p.m. & $4 / 21 / 2015$ & $4: 15$ p.m. & $4 / 21 / 2015$ \\
\hline 6:30 p.m. & $4 / 17 / 2015$ & $5: 15$ p.m. & $4 / 17 / 2015$ \\
\hline & & $5: 45$ p.m. & $4 / 15 / 2015$ \\
\hline
\end{tabular}

The results show that the largest source of travel delay for the MetroRapid is signal delay (Figure 4-1). Dwell time and turn out delay are not major contributors. Furthermore, no significant delay was observed in the vicinity of the new crosswalks on Fletcher Avenue. Signal delay, on the other hand, accounted 24 percent of the travel delay in the northbound direction and 21 percent of the travel delay in the southbound direction. 

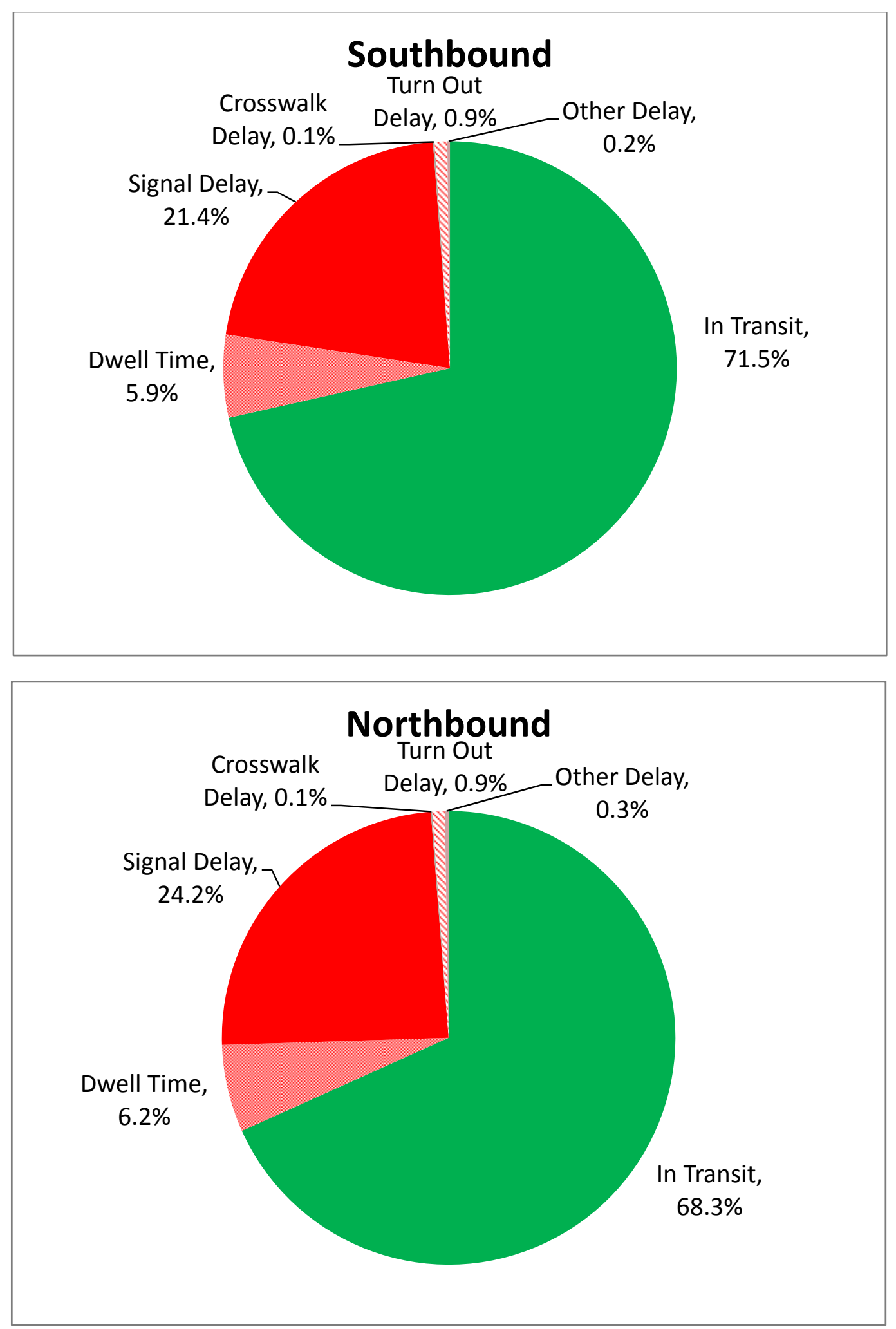

Figure 4-1 Components of Travel Delay 
Transit signal priority (TSP) is provided for the MetroRapid but not for the Route 2. A total of 37 intersections along the route are equipped with transit signal priority (TSP), of which 14 are in Hillsborough County and 23 are in the City of Tampa. All 14 of the county intersections have the TSP activated. However, only 8 of the 23 city intersections have it activated. They are Twiggs, Cass, Scott, Henderson, 7th Ave, Palm, Columbus, and Floribraska. Five of the non-operational intersections in the city are on major roadways with access to I-275. The Florida Department of Transportation (FDOT) has delayed activating these intersections until it can be demonstrated that there would be no negative impact to the interstate.

Figure 4-2 and Figure 4-3 show the locations and extent of the signal delay. The times shown are average delay in seconds. In the northbound direction, the greatest amount of delay was observed at Hillsborough Avenue (103 seconds). In the southbound direction, it was at Busch Boulevard (110 seconds). Also, there is a string of signal delays in downtown Tampa along Morgan Street near the Marion Transit Center. Individually, these signal delays are small in magnitude, but collectively they add up to 57 seconds. In other words, it takes a full extra minute to get out of downtown. At the north end of the line, there is nearly a minute of delay at the left turn into Hidden River Parkway. 


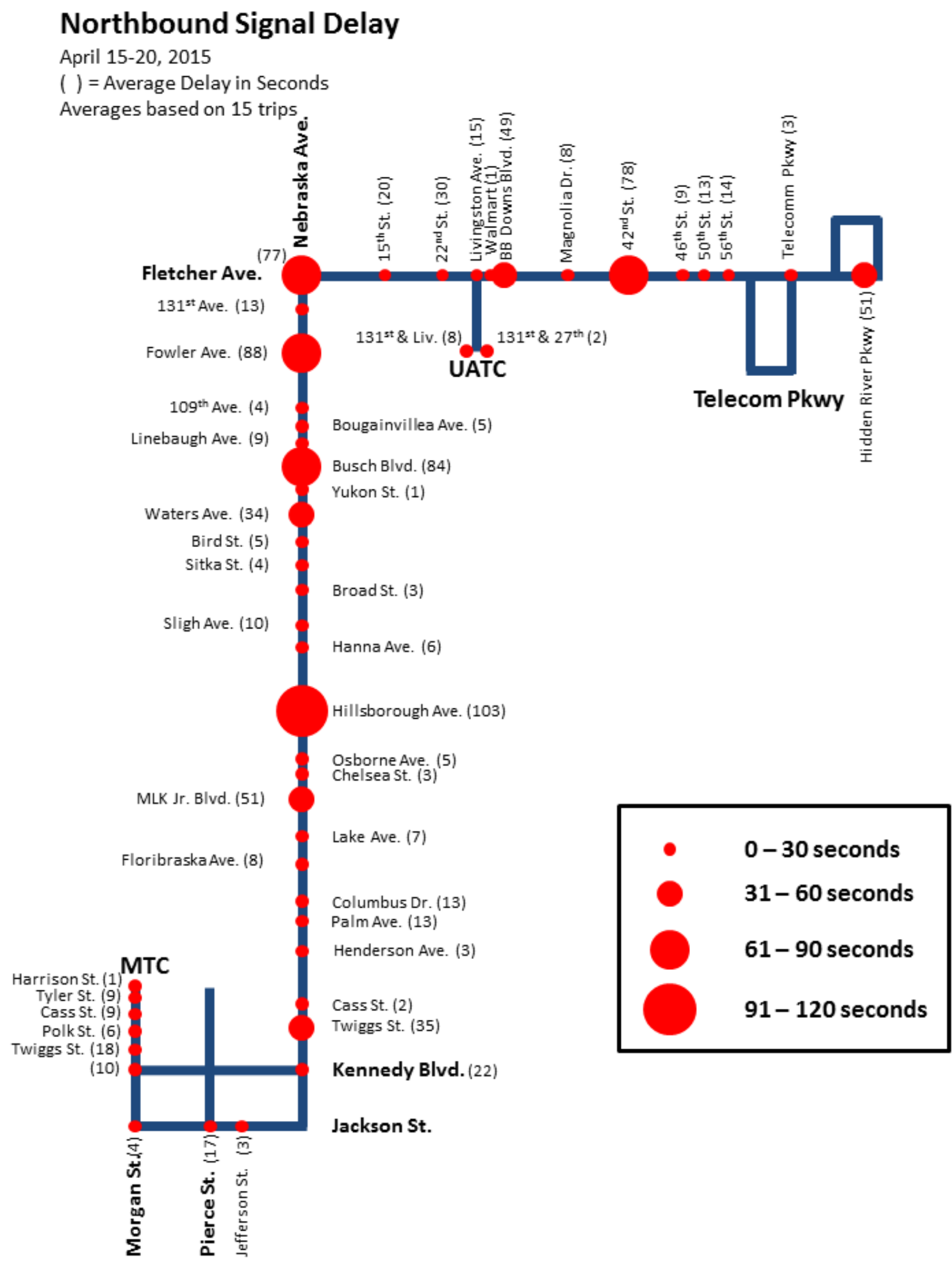

Figure 4-2 Traffic Signal Delay Northbound 


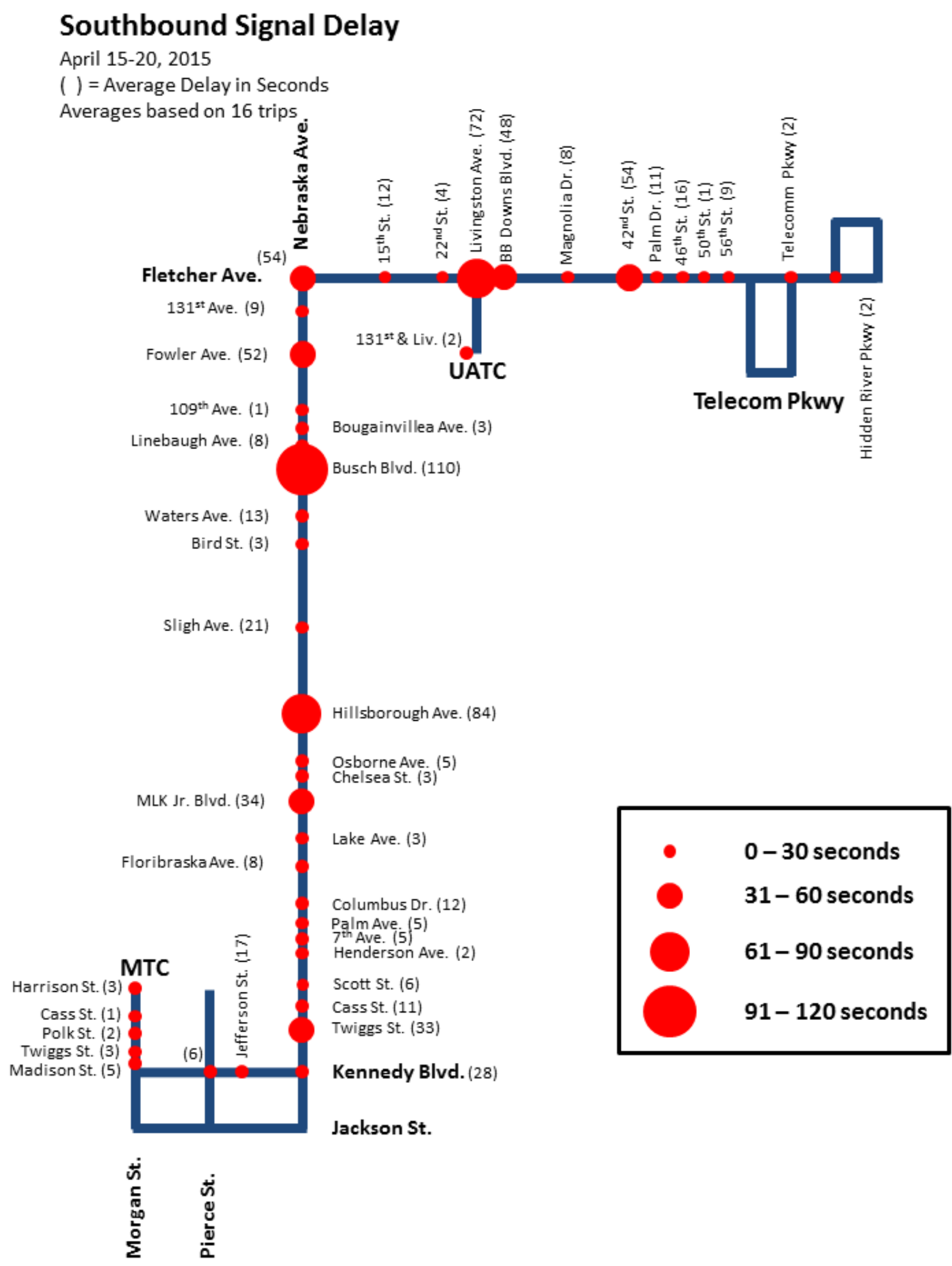

Figure 4-3 Traffic Signal Delay Southbound 
As stated before, the MetroRapid has several operational features which give it an advantage over the Route 2. They include TSP and fewer, farther spaced stations. These features should translate into a travel time advantage for the MetroRapid. In order to quantify how much of an advantage there is, automated vehicle location (AVL) data was compared for the two routes. $A$ month's worth of AVL data was compared for March 2015. In order to make a fair comparison, the analysis was restricted to the same start and endpoints (MTC and UATC). Also, since the Route 2 has longer hours of service, the comparative analysis was restricted to trips that fell within the MetroRapid's start and end time. The results are shown below in Table 4-2.

The average travel time of the MetroRapid between MTC and UATC is 45.1 minutes, which is two minutes more than the scheduled travel time of 43 minutes. HART's on-time performance standard is 5 minutes or less. The MetroRapid has a 10 minute advantage over the Route 2, which takes 55.2 minutes to travel the corridor. Furthermore, the standard deviation of travel time on the MetroRapid is almost two and half minutes less than the Route 2. In other words, the travel time of the MetroRapid is more consistent.

Table 4-2 Travel Time Comparison for MetroRapid and Route 2 (March 2015)

\begin{tabular}{|l|c|c|}
\hline & MetroRapid & Route 2 \\
\hline Number of trips & 601 & 539 \\
\hline Scheduled travel time & 43 minutes & $48-49$ minutes \\
\hline Actual average travel time & 45.1 minutes & 55.2 minutes \\
\hline Standard deviation & 5.7 minutes & 8.1 minutes \\
\hline
\end{tabular}




\section{Chapter 5 Passenger Surveys}

CUTR conducted an on-board passenger survey of MetroRapid riders in April 2015. 344 surveys were collected. Average daily ridership on the MetroRapid in April 2015 was 2,252. Using that figure as the population size and 344 as the sample size yields a confidence interval of \pm 4.9 at the 95 percent confidence level. Where possible, the results of the MetroRapid survey were compared to the findings from a system-wide survey that HART conducted in April 2014.

When it comes to gender and access to an automobile, MetroRapid riders are not much different from the rest of HART riders. HART riders as a whole are evenly split between male and female while MetroRapid riders tilt slightly more male. Both groups of riders include a large percentage that do not have access to an automobile (61\% MetroRapid; 63\% HART).

Table 5-1 Are you male or female?

\begin{tabular}{l|r|r|}
\cline { 2 - 3 } \multicolumn{1}{c|}{} & \multicolumn{2}{c|}{ MetroRapid } \\
\cline { 2 - 4 } Male & Number & Percent \\
\cline { 2 - 4 } Female & 186 & $54 \%$ \\
\cline { 2 - 4 } & 149 & $45 \%$ \\
\cline { 2 - 4 }
\end{tabular}$\quad$\begin{tabular}{r|r|r|}
\multicolumn{2}{c|}{ HuRT } \\
\cline { 2 - 4 }
\end{tabular}

Note: HART figures are from the April 2014 system wide survey

Table 5-2 How many automobiles do you have in your household?

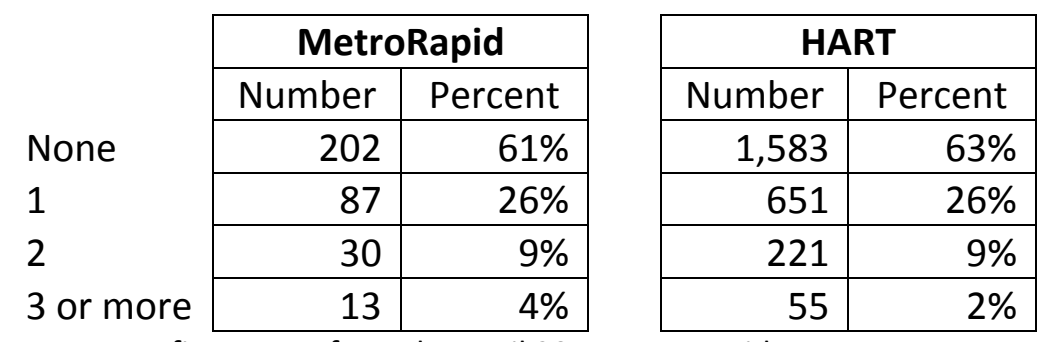

Note: HART figures are from the April 2014 system wide survey

MetroRapid riders were asked how they would make their trip if not by bus (Table 5-3). Only 13 percent said that they would drive. That is not surprising given that 61 percent said they do not have an automobile in their household. 
Table 5-3 How would you make this trip is not by bus?

\begin{tabular}{|l|r|r|}
\hline \multicolumn{1}{|c|}{ Response } & Number & Percent \\
\hline Walk & 66 & $20 \%$ \\
\hline Drive & 44 & $13 \%$ \\
\hline Ride with someone else & 77 & $23 \%$ \\
\hline Bicycle & 40 & $12 \%$ \\
\hline Taxi & 33 & $10 \%$ \\
\hline Wouldn't make trip & 46 & $14 \%$ \\
\hline Other & 24 & $7 \%$ \\
\hline Total & 330 & $100 \%$ \\
\hline
\end{tabular}

Less than half (45\%) of MetroRapid riders said that had transferred from another bus (Table 5-4). Among those who did, the top three transfer routes mentioned were the Route 34 (Hillsborough Avenue), the Route 6 (56th Street), and the Route 2 (Nebraska Avenue). In regards to the Route 2 , what is occurring most likely is riders taking the first bus that comes along and transferring if they need to travel further east on Fletcher Avenue.

Table 5-4 Before getting on the MetroRapid, did you transfer from another route?

\begin{tabular}{|l|r|r|}
\hline \multicolumn{1}{|c|}{ Response } & Number & Percent \\
\hline Yes & 154 & $45 \%$ \\
\hline No & 187 & $55 \%$ \\
\hline Total & 341 & $100 \%$ \\
\hline
\end{tabular}

The findings were similar when asking riders whether they transferred to another route after leaving the MetroRapid (Table 5-5). Again, less than half (43\%) indicated that they transferred. The top two responses were the Route 34 (Hillsborough Avenue) and the Route 6 (56th Street).

Table 5-5 After you leave the MetroRapid, will you transfer to another route?

\begin{tabular}{|l|r|r|}
\hline \multicolumn{1}{|c|}{ Response } & Number & Percent \\
\hline Yes & 148 & $43 \%$ \\
\hline No & 193 & $57 \%$ \\
\hline Total & 341 & $100 \%$ \\
\hline
\end{tabular}

Riders responded differently when asked if they ever ride the Route 2 instead of the MetroRapid (Table 5-6). 64\% indicated yes. Anecdotal comments made on some of the surveys indicate that these people use the Route 2 in the evenings and/or on weekends when the MetroRapid does not operate. 
Table 5-6 Do you ever ride the Route 2 instead of the MetroRapid?

\begin{tabular}{|l|r|r|}
\hline \multicolumn{1}{|c|}{ Response } & Number & Percent \\
\hline Yes & 217 & $64 \%$ \\
\hline No & 121 & $36 \%$ \\
\hline Total & 338 & $100 \%$ \\
\hline
\end{tabular}

Nearly half (49\%) of MetroRapid riders said they were using it to get to work (Table 5-7). The next largest response was school.

Table 5-7 What is the primary purpose of this trip today?

\begin{tabular}{|l|r|r|}
\hline Trip Purpose & Number & Percent \\
\hline Work & 169 & $49 \%$ \\
\hline School & 44 & $12 \%$ \\
\hline Shopping & 23 & $7 \%$ \\
\hline Recreation & 15 & $4 \%$ \\
\hline Errands & 40 & $12 \%$ \\
\hline Medical & 36 & $11 \%$ \\
\hline Other & 17 & $5 \%$ \\
\hline Total & 344 & $100 \%$ \\
\hline
\end{tabular}

56 percent of the riders said they use the MetroRapid five days a week (Table 5-8). Another 12 percent said they ride it four days a week.

Table 5-8 How many days a week do you ride the MetroRapid?

\begin{tabular}{|l|r|r|}
\hline \multicolumn{1}{|c|}{ No. of Days } & Number & Percent \\
\hline Less than once a week & 12 & $4 \%$ \\
\hline 1 & 10 & $3 \%$ \\
\hline 2 & 24 & $7 \%$ \\
\hline 3 & 61 & $18 \%$ \\
\hline 4 & 42 & $12 \%$ \\
\hline 5 & 193 & $56 \%$ \\
\hline Total & 342 & $100 \%$ \\
\hline
\end{tabular}

Only a quarter of the riders (25\%) said they used a ticket vending machine (TVM) to purchase their ticket (Table 5-9). Ticket vending machines are located at 12 of the 59 stations. Almost all of them are at high boarding locations (see Appendix C Station Type/Ticket Vending Machine Location Map). This means that even at stations like Marion Transit Center and University Area Transit Center, most riders are not using the TVM. 
Table 5-9 Did you use the ticket vending machine to purchase your ticket?

\begin{tabular}{|l|r|r|}
\hline Response & N & Percent \\
\hline Yes & 85 & $25 \%$ \\
\hline No & 251 & $75 \%$ \\
\hline Total & 336 & $100 \%$ \\
\hline
\end{tabular}

Since 68 percent of the riders report using the MetroRapid at least four days a week, a possible reason they do not use the TVM is because they have a 31-day unlimited ride card or some other fare card. To test this theory, a cross tabulation was performed to see if less frequent riders were more likely to use the TVM than frequent riders. The thought is that less frequent riders would be more likely to use the TVM because they do not own a 31-day fare card. The results are shown in Table 5-10. Across all levels of frequency, most riders do not use the TVM. Oddly, riders who use MetroRapid less than once a week were also the least likely to use to the TVM.

Table 5-10 Cross Tabulation (Frequency of Riding vs. Use of TVM)

\begin{tabular}{|c|c|c|c|c|c|}
\hline & \multicolumn{4}{|c|}{$\begin{array}{l}\text { Did you use the } \\
\text { ticket vending } \\
\text { machine to purchase } \\
\text { your ticket? }\end{array}$} \\
\hline & & \multicolumn{2}{|c|}{ Yes } & \multicolumn{2}{|c|}{ No } \\
\hline \multirow{6}{*}{$\begin{array}{l}\text { How many } \\
\text { days a week } \\
\text { do you ride } \\
\text { the } \\
\text { MetroRapid? }\end{array}$} & Less than once a week & 1 & $8 \%$ & 11 & $92 \%$ \\
\hline & 1 & 3 & $33 \%$ & 6 & $67 \%$ \\
\hline & 2 & 8 & $33 \%$ & 16 & $67 \%$ \\
\hline & 3 & 13 & $22 \%$ & 46 & $78 \%$ \\
\hline & 4 & 14 & $33 \%$ & 28 & $67 \%$ \\
\hline & 5 & 45 & $24 \%$ & 143 & $76 \%$ \\
\hline
\end{tabular}

Although the number of riders who indicated using a TVM was small, nearly all of them (94\%) indicated that the TVM was easy to use (Table 5-11).

Table 5-11 If yes, was it easy to use?

\begin{tabular}{|l|r|r|}
\hline \multicolumn{1}{|c|}{ Response } & N & Percent \\
\hline Yes & 73 & $94 \%$ \\
\hline No & 5 & $6 \%$ \\
\hline Total & 78 & $100 \%$ \\
\hline
\end{tabular}

MetroRapid riders were asked to rate on a scale of 1 to 5 the importance of several factors when deciding to use the MetroRapid. The factors are shown below in Table 5-12. They were then asked to rate on a scale of 1 to 5 their level of satisfaction with those factors when riding the MetroRapid. For the scale of how important a given factor was, 1 equaled "not at all 
important" and 5 equaled "extremely important". For level of satisfaction, the scale was as follows: 1 (very poor), 2 (poor), 3 (fair), 4 (good), 5 (very good). MetroRapid riders indicated that all of the factors were important to them. The one slight exception was comfort at the station. It rated the lowest at 4.2, which still translates as being an important factor. In terms of customer satisfaction, the MetroRapid scored well. All but one of the factors had a score of 4 or greater. The only exception was hours of service, which rated a 3.9. During the survey, several of the surveyors reported being told by passengers that they wished the MetroRapid had weekend service. It was already noted earlier that 64 percent of the riders said they sometimes ride the Route 2 . Most likely, they are riding the Route 2 at night or on the weekend when the MetroRapid is not in service.

Table 5-12 Level of Importance and Level of Satisfaction with Various Travel Factors

\begin{tabular}{|l|r|r|}
\hline \multicolumn{1}{|c|}{ Factor } & How Important & How Satisfied \\
\hline Travel time & 4.6 & 4.4 \\
\hline Reliability & 4.6 & 4.4 \\
\hline Service frequency & 4.6 & 4.3 \\
\hline Hours of service & 4.4 & 3.9 \\
\hline Comfort at the station & 4.2 & 4.1 \\
\hline Safety at the station & 4.4 & 4.1 \\
\hline Comfort during the ride & 4.4 & 4.5 \\
\hline Safety during the ride & 4.6 & 4.5 \\
\hline Overall opinion of MetroRapid & & 4.4 \\
\hline
\end{tabular}

Further analysis was done to see if men and women rated the MetroRapid differently. Although the mean scores did differ, statistically speaking they were the same (Table 5-13).

Table 5-13 Levels of Satisfaction by Gender

\begin{tabular}{|l|r|r|r|}
\hline \multicolumn{1}{|c|}{ Factor } & \multicolumn{2}{c|}{ Satisfaction } & \multirow{2}{*}{ p Value } \\
\cline { 1 - 3 } & \multicolumn{1}{c|}{ Male } & \multicolumn{1}{c|}{ Female } & \\
\hline Travel time & 4.40 & 4.34 & 0.500 \\
\hline Reliability & 4.42 & 4.34 & 0.382 \\
\hline Service frequency & 4.34 & 4.27 & 0.532 \\
\hline Hours of service & 3.87 & 3.93 & 0.669 \\
\hline Comfort at the station & 4.13 & 4.03 & 0.419 \\
\hline Safety at the station & 4.11 & 3.99 & 0.307 \\
\hline Comfort during the ride & 4.45 & 4.47 & 0.821 \\
\hline Safety during the ride & 4.49 & 4.55 & 0.412 \\
\hline Overall opinion of MetroRapid & 4.36 & 4.40 & 0.644 \\
\hline
\end{tabular}

Note: Since all of the $p$ values were $>0.05$, there was no statistical significance to the difference in responses between males and females. 
Finally, HART was interested in knowing how many MetroRapid riders use the OneBus Away phone app, which provides users with real time bus arrival information. Less than half (45\%) said yes.

Table 5-14 Do you use the OneBusAway phone app?

\begin{tabular}{|l|c|r|}
\hline \multicolumn{1}{|c|}{ Response } & N & Percent \\
\hline Yes & 147 & $45 \%$ \\
\hline No & 183 & $55 \%$ \\
\hline Total & 330 & $100 \%$ \\
\hline
\end{tabular}




\section{Chapter 6 Conclusion}

The MetroRapid represents Hillsborough Area Regional Transit's first foray into bus rapid transit. Built at a total cost of $\$ 34.75$ million, or $\$ 1.98$ million per mile, it is at the low end of the cost spectrum for BRT projects. MetroRapid includes several key BRT features such as branding of the stations and buses, increased station spacing, ticket vending machines at 12 of the 59 stations, and transit signal priority (TSP).

The greatest advantage of the MetroRapid is the travel time savings it offers over the parallel Route 2. Not only is it 10 minutes faster, but its travel time is more consistent. Consequently, some Route 2 riders have switched to the MetroRapid. In fact, ridership on the Route 2 dropped 30 percent in the MetroRapid's first full month of service and has remained at a lower level since then. Despite that, there has still been a 10 percent net gain in ridership on the Nebraska Avenue corridor when looking at combined ridership on the MetroRapid and Route 2. In terms of service effectiveness, the MetroRapid is not the best performing route, but neither is it the worst. Out of HART's 46 fixed routes, it ranked $23^{\text {rd }}$ for passengers carried per revenue hour and $18^{\text {th }}$ for passengers carried per revenue mile. Overall, MetroRapid riders are satisfied with the service. In the rider surveys that were conducted, the MetroRapid scored "Good" on 8 of 9 service factors. The only exception was "Hours of Service", which rated "Fair".

The MetroRapid carries almost 49,000 riders per month on average. Almost all of it is on the segment between Marion Transit Center and University Area Transit Center. An analysis of the MetroRapid's automated passenger counter (APC) data revealed that boardings and alightings drop off significantly between the University Area Transit Center and the Hidden River Park and Ride Lot. Based on that information, the first recommendation of this report is to better advertise the Hidden River Park and Ride Lot, especially to workers at the University of South Florida. Faculty, staff, and students can ride HART buses for free with their university ID card. They can potentially save $\$ 183$ to $\$ 1,076$ a year on parking depending on which type of parking pass they have. However, many of them may not even be aware of the existence of the park and ride lot.

The second recommendation is to consider improving the MetroRapid's service frequency on Fletcher Avenue to every 15 minutes. Currently, only the Nebraska Avenue portion of the MetroRapid has 15 minute frequency. The 30 minute frequency, in addition to the lack of awareness of the Hidden River Park and Ride Lot, may be hindering better performance along Fletcher Avenue.

The third recommendation is to consider asking the Florida Department of Transportation to activate the TSP at Hillsborough Avenue and Busch Boulevard, and the City of Tampa to activate the intersections in downtown along Morgan Street. Although the MetroRapid is 10 minutes faster than the Route 2, traffic signal delay still accounts for between 21 and 24 percent of its total travel time. Hillsborough Avenue and Busch Boulevard were the two largest sources of traffic signal delay. The intersections along Morgan Street, though individually small in magnitude, collectively add to the time it takes for the MetroRapid to get out of downtown. 
Based on the fact that dwell time was not observed to be an issue, this report does not recommend adding ticket vending machines at the remaining stations. If and when ridership on the MetroRapid increases, this report recommends rechecking the dwell times and then deciding whether additional TVMs would be warranted.

The fourth recommendation is that HART reconsider adding real time bus arrival information at the stations (both on the existing MetroRapid and any future MetroRapid lines). This recommendation is based on the fact that only 45 percent of the riders indicated using the OneBus Away app. In this day in age of the smart phone, there is a tendency to assume that apps will solve everything. However, 55 percent of MetroRapid riders, for whatever reason, do not use the app. 
Appendix A MetroRapid Route Map 


\section{Metroliapid}

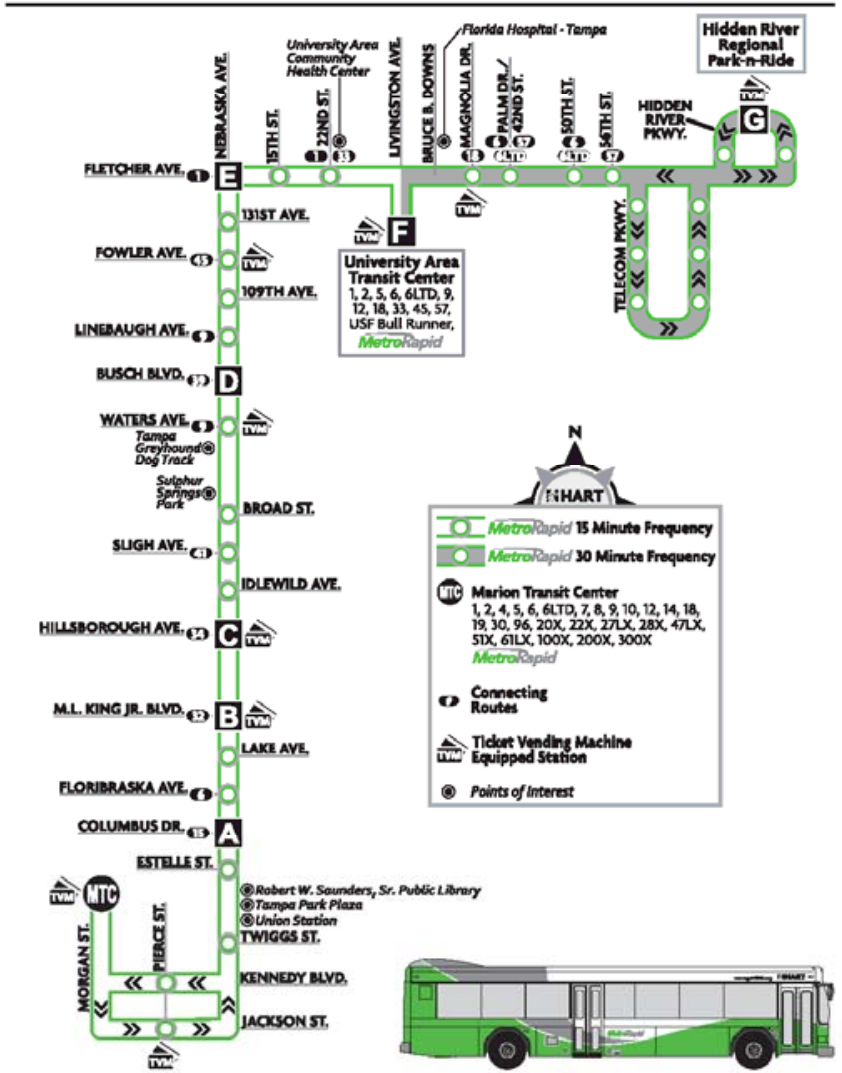

NOW IN SERVICE
NORTHBOUND WEEKDAY ONLY

Downtown Tampa to University Area Transit Center/

Hidden River Regional Park-n-Ride

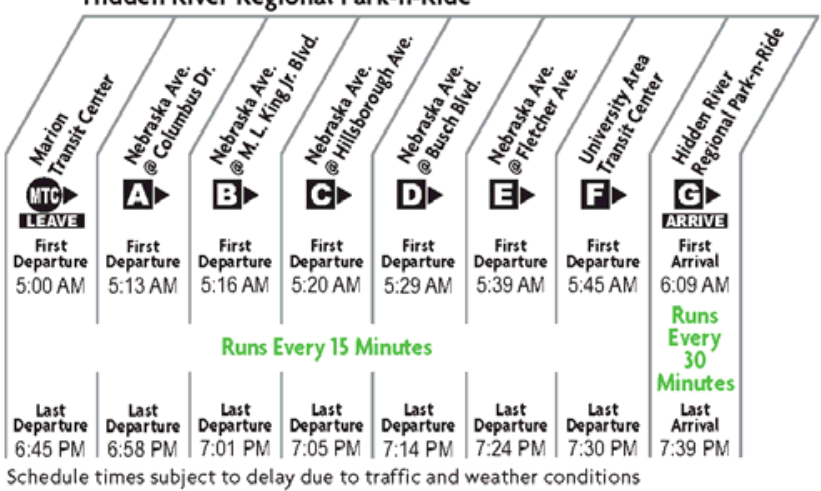

\section{SOUTHBOUND WEEKDAY ONLY}

University Area Transit Center to Downtown Tampa
Uniden River Regional Park-n-Ride/

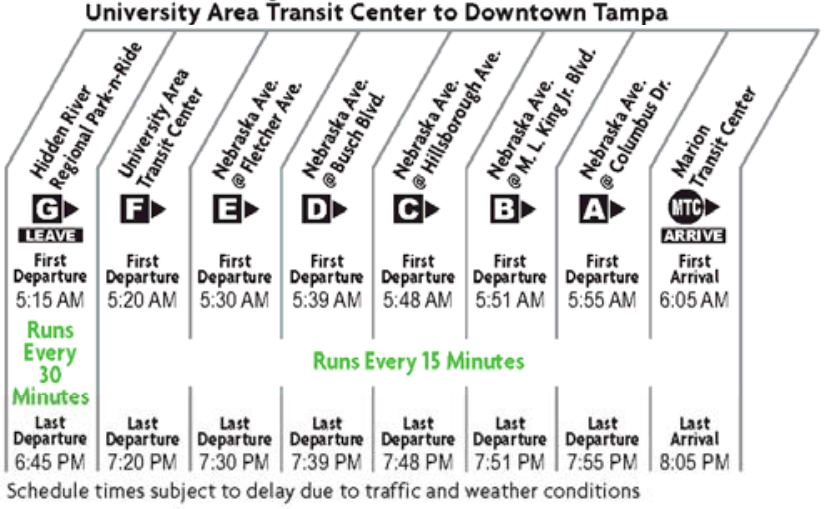

\section{FHART}

HART Customer Service Department at (813) 254-HART (4278)

Source: HART 
Appendix B Route 2 Map 


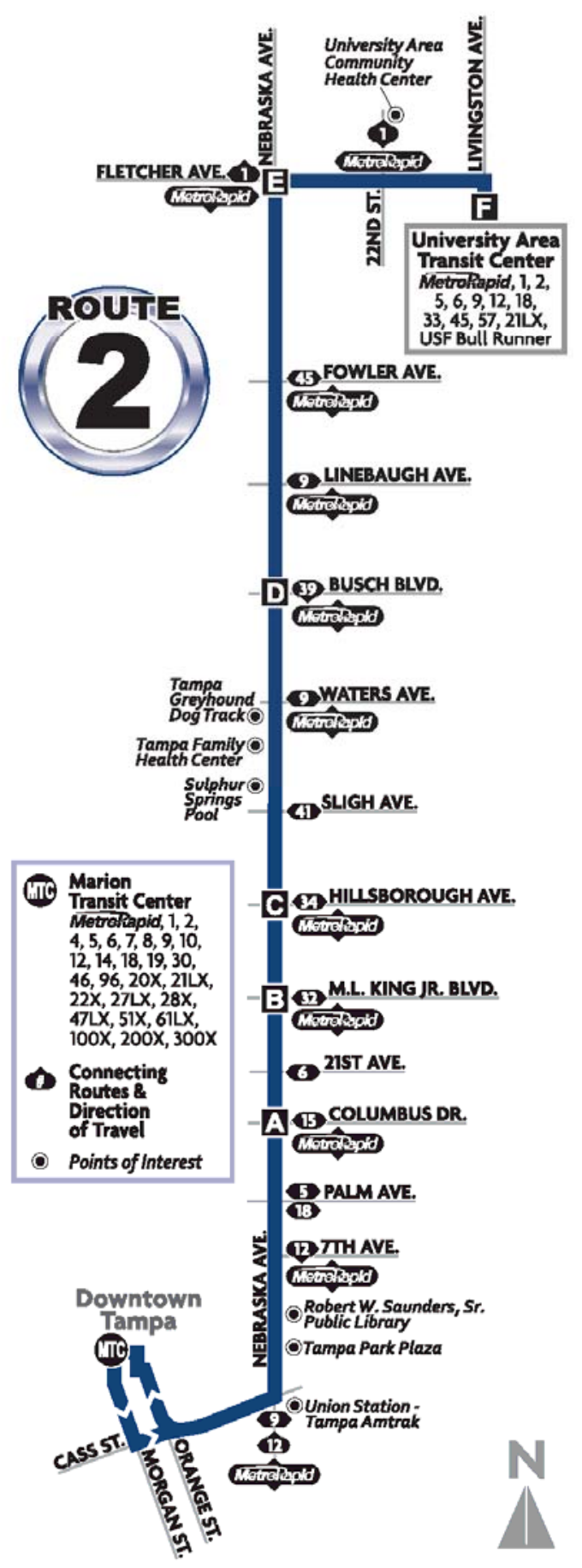

Source: HART 
Appendix C Station Type/Ticket Vending Machine Location Map 


\section{NORTH/SOUTH CORRIDOR}

STATION TYPE/TVM LOCATION MAP

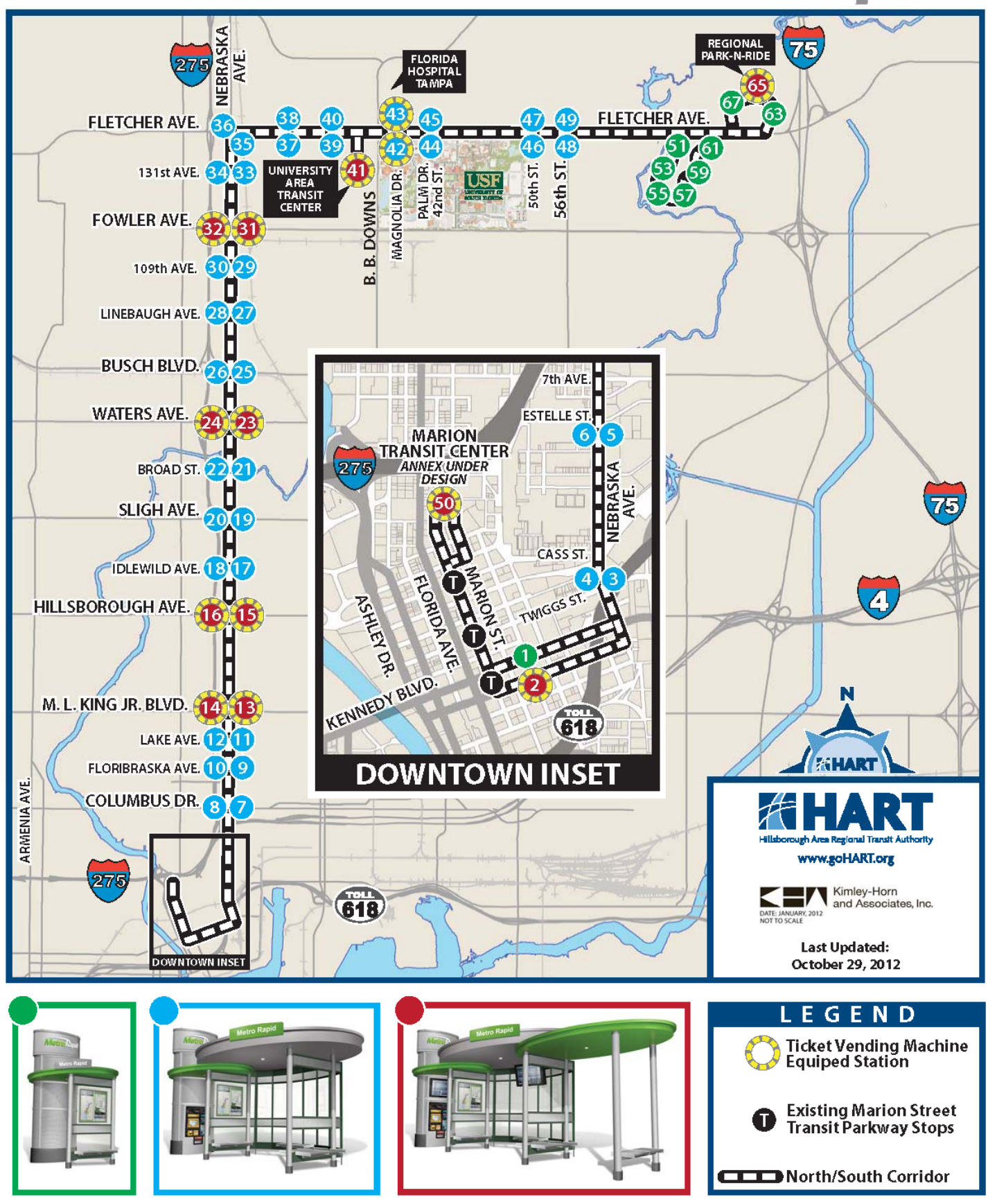

Source: HART 